\title{
THE ForgotTen CONSTITUTION: THE NATURAL RESOURCES TRANSFER AGREEMENTS AND INDIAN LIVELIHOOD RIGHTS, CA. 1925-1933
}

\author{
FrANK J. TOUGH*
}

This article forms Part I of a two part legal-historical analysis of the Natural Resources Transfer Agreement (NRTA), the processes and circumstances that gave rise to its enactment. and the subsequent implications

historical and contemporary --for the livelihood rights of Aboriginal peoples. In this Part, the author critically examines historical evidence surrounding the agreements that the Prairie Provinces of Alberta, Manitoba, and Saskatchewan entered into with the Dominion government. In doing so, the author concludes that. to date. legal interpretations of the NRTA and the respective provincial agreements have been short-sighted and incomplete. As such, they are deeply troubling and represent a site for further critical legal analysis and judicial reconsideration.
Cet article représente la première de deux parties d'une analyse historico-légale de la Convention sur le transfert des ressources naturelles: elle porte sur les processus et les circonstances qui ont donné lieu à sa promulgation et aux implications ultérieures historiques et contemporaines .. sur les droits de subsistance des Autochtones. Dans cette première partie, l'auteur examine, d'un point de vue critique. la preuve historique entourant les ententes que les provinces des Prairies, à savoir l'Alberta. le Manitoba et la Saskatchewan. ont conclu avec le gouvernement du Dominion. En ce faisant. l'auteur conclut qu'à ce jour, les interprétations juridiques de la Convention sur le transfert des ressources naturelles et les ententes provinciales respectives sont incomplètes et imprévoyantes. Elles sont inquiétantes et devraient faire l'objet d'une analyse légale critique plus approfondie et d'une reconsidération juridique.

\section{TABLE OF CONTENTS}

I. INTRODUCTION ............................. 1000

II. The Political ANd Legislative Processes

OF TRANSFERRING RESOURCES $\ldots \ldots \ldots \ldots \ldots \ldots \ldots \ldots \ldots$

III. THE TREATY HUNTING AND FISHING RIGHT IN

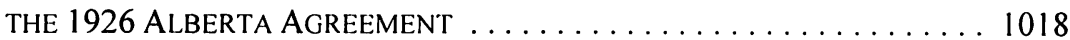

IV. THE INDIAN LIVELIHOOD RIGHT IN THE

1929 MANitoba AgREEMENT . . . . . . . . . . . . . . . . . . . . 1025

V. REDEFINING INDIAN LIVELIHOOD RIGHTS:

THE 1926 ANd 1929 AgreEments Compared .............. 1034

VI. THE Transfer of Fishing Rights to the Provinces ......... 1039

VII. HISTORICAL RECONSTRUCTION OF THE NRTA SUMMARIZED . . . . . . . 1043

APPENDIX A . . . . . . . . . . . . . . . . . . . . . . . . . . . 1045

APPENDIX B ................................. 1046

APPENDIX C . . . . . . . . . . . . . . . . . . . . . . . . . . . . 1047

APPENDIX D . . . . . . . . . . . . . . . . . . . . . . . 1048

Professor, School of Native Studies, University of Alberta. 
It is characteristic of lawyers that as soon as they conclude an agreement,

they begin to find the need of discovering what its terms mean.

Prime Minister William Lyon Mackenzie King, $1928^{\prime}$

\section{INTRODUCTION ${ }^{2}$}

A provision for Indian hunting, fishing, and trapping rights stemming from the 1930 transfer of natural resources from the Dominion of Canada to the Provinces of Manitoba, Alberta, and Saskatchewan has been an enduring legal controversy. Most recently, in $R . v$. Blais, ${ }^{3}$ the Supreme Court of Canada had to contend with a Metis hunting right defense based on the assertion that the Metis were Indians for the purpose of para. 12 of the Manitoba Natural Resources Agreement. ${ }^{4}$ The Court dismissed the appeal and, most interestingly, repeatedly held that the analysis of the right "must be anchored in the historical context of the provision." Not only has the legal system not encountered a grounded historical analysis in respect of the effect of the Natural Resources Transfer Agreement" on treaty rights, but now the requirement of developing an historical analysis will prove to something of a task to those trained to find meaning by restricting context. The wording of this paragraph of the $N R T A$ is often cited by courts and legal academic literature mechanically and completely without historical depth when addressing treaty rights in the Prairie Provinces:

12. [13] In order to secure to the Indians of the Province the continuance of the supply of game and fish for their support and subsistence, Canada agrees that the laws respecting game in force in the Province from time to time shall apply to the Indians within the boundaries thereof, provided, however, that the said Indians shall have the right, which the Province hereby assures to them, of hunting, trapping and fishing game and fish for lood at all seasons of the year on all unoccupied Crown lands and on any other lands to which the said Indians may have a right of access. ${ }^{7}$

1 After meeting with those responsible with the Manitoba Resources commission. Mackenzie King wrote in his diary: "spent nearly I 1/4 hrs with Judge Turgeon, Dunning, Stewart, \& Mr. Forke going over basis of enquiry re natural resources transfer to Manitoba. It is characteristic of lawyers that as soon as they conclude an agreement, they begin to find the need of discovering what its terms mean" (Diaries of William Lyon Mackenzie King (2 November 1928) ()ttawa. National Archives of Canada [NAC (MG26-J/3), online: NAC ' < http://king.archives.ca> [King Diaries]).

2 This discussion has had the benefit of an earlier analysis of para. 12 of the NRTA (see Frank Tough, "Introduction to Documents: Indian Hunting Rights, Natural Resources Transfer Agreements and Legal Opinions from the Department of Justice" (1995) 10 Native St. Rev. 121.

R. v. Blais, [2003] 2 S.C.R. 236 [Blais].

Manitoba Natural Resources Agreement, S.M. 1930, c. 30 [Manitoba agreement].

Blais, supra note 3 at para. 40.

All three provincial agreements (see infra note 7) are Schedules to the British North America Act. 1930. (U.K.), c. $26[B N A A c t]$, renamed the Constitution Act, 1930. (U.K.). 20 \& 21 (ieo. V.. c. 26. [Constitution Act, 1930], reprinted in R.S.C. 1985, App. II, No. 26; the long title of this $A c t$ is “An Acl to Amend the British North America Acts, 1867 to 1916." By convention, the confirmed agreements are referred to as the Natural Resources Transfer Agreement, 1930) [NRTA].

In the Alberta and Saskatchewan agreements, the Indian hunting right is found in para. 12, whereas the same wording is found in para. 13 in the Manitoba agreement. Three Memorandums of Agreement were made: (1) Dominion of Canada and the Province of Manitoba (14 December 1929); (2) Dominion of Canada and the Province of Alberta (14 December 1929); and somewhat later; (3) Dominion of Canada and Province of Saskatchewan (20 March 1930). The content of these agreements is very similar. The sections of the agreements are usually referred to as paragraphs or clauses. These agreements were enacted concurrently at the provincial, federal, and imperial levels (sec The Alberia Natural Resources Act, S.A. 1930, c. 21 [Alberta agreement], confirmed as S.C. 1930, c. 3: Manitoba agreement, supra 
Considerable efforts have gone into explaining what this provision really means and what sort of legal protection it affords, largely unaided by the records that created the provision in the first place. However, until Blais, little or no consideration had been given to the plain and simple meaning of the words "Indians of the Province." As this article will demonstrate, some rather sophisticated legal reasoning has been constructed upon historically inaccurate conjectures. The definition that was recently "adopted" in Blais conflicts with the courts' earlier interpretations of the right.

Today, the NRTA is largely remembered because of treaty rights litigation. In point of fact, in 1930, Indian livelihood was only one issue involved in the transfer of vast lands with natural resources and the compensation to the provinces from the federal government for the loss of enjoyment of those lands and resources. The Preamble to the Alberta Agreement scheduled with the Alberta Natural Resources Act, 1930 identified the purpose: "And Whereas it is desirable that the Province should be placed in a position of equality with the other provinces of Confederation with respect to the administration and control of its natural resources." 8 Primary historical research reveals that serious consideration was given to protecting several Indian interests involved in the transfer and that the records of negotiations indicate that the wording of the paragraph that would become the Indian livelihood right was not a static concept. While the transfer of resources entailed a wide range of trusts and obligations concerning resource use and land tenure, the general constitutional protection for these rights indicates a process that is very relevant to contemporary Aboriginal rights. It should be stated at the outset that the Indian livelihood provision of the NRTA is a constitutional right; it nevertheless has been given a series of meanings by the courts. The final wording of para. 12 is intricate and complex, but since it arose from a process that amended the Constitution, it provides some sort of constitutional protection for Indian livelihood. Thus, in the Prairie Provinces, the legacy of expressed constitutional protection for the concept of Indian rights does not begin, as is often assumed, in 1982.

Not only have the Indian livelihood rights of the NRTA been interpreted legally without the benefit of considering the records that document the intentions of the drafters or the historical/political context in which this amendment to the $B N A A c t^{9}$ developed; also become snarled with the prairie Indian treaties. ${ }^{10}$ The pre-existing treaty livelihood rights are thought to have been altered by the NRTA. As a consequence, several unsound assumptions have been made about this aspect of our constitution which not only lack empirical support, but are also largely contradicted by historical evidence. Another common operative assumption, held

note 4, confirmed as S.C. 1930, c. 29; The Saskatchew'an Natural Resources Act. S.S. 1930, c. 87 [Saskatchewan agreement], confirmed as S.C. 1930 , c. 41 ; and the Constitution Act, 1930, ibid. The agreement was made in 1929, but it was enacted in 1930. The long title of the Imperial statute is " $\mathrm{An}$ Act to confirm and give effect to certain agreements entered into between the Government of the Dominion of Canada and the Governments of the Provinces of Manitoba. British Columbia. Alberta and Saskatchewan respectively." The agreement with British Columbia involved the railroad lands and the Peace River block that had been administered by the Department of the Interior.

Alberta agreement, ibid.

Supra note 6 .

An historical survey of most prairie treaties is found in Arthur J. Ray, Jim Miller \& Frank J. Tough. "Bounty and Benevolence": A History of Saskatcherran Treaties (Montreal: McGill-Queen's University Press, 2000); see also Harold Cardinal \& Walter Hildebrandt. Treaty Elders of Saskatchewan: (Ou' Dream is That Our Peoples Will One Day Be Clearly Recognized as Nations (Calgary: University ol Calgary Press, 2000). 
especially by advocates, is that are no archival records concerning the NRTA or that such records cannot inform the courts of what the drafters of this major constitutional amendment were considering when dealing with Indian interests in the land. Enquiry into the surrounding circumstances in which the BNA Act was amended in 1930 has lagged far behind the understandings that courts have given para. 12. Devoid of historical facts, efforts to link treaty hunting, trapping, and fishing rights with para. 12 of the NRTA becoming increasingly convoluted and, with each subsequent decision, further removed from the actual processes that devised a constitutionally protected Indian livelihood right. Such criticisms are tempered by the fact that lawyers and judges are handicapped by the absence of published historical literature on the political developments that shaped the transfer of resources. " Given that over several decades, prime ministers and premiers, cabinet ministers, senior officials all seemed to have expended as much energy at working out this transfer the of lands and resources as did the "Fathers of Confederation" at fashioning the original BNA Act in 1867,'2 the absence of serious academic analysis of the Constitution Act, 1930 points to a major deficiency in our national history. ${ }^{13}$ Similarly, surveys of Aboriginal rights offer few insights on the NRTA.

In Native Law, Jack Woodward provided a clear explanation of aspects of the hunting provision by reviewing jurisprudence on such issues as the failure of provincial governments to limit the agreement and the right of access. Woodward succinctly explained the Court's interpretation of para. 12 of the NRTA as entailing a treaty right:

The agreements effectively merged and consolidated the treaty rights of Indians in the area and restricted the power of provinces to regulate the Indians' right to hunt for food. This brought about two important differences in the rights themselves. Under the treaties, hunting rights were general; under the agreements, hunting has been restricted to hunting for food. Under treaties, hunting rights were restricted to the tract of the land surrendered by the treaty; under the agreements hunting rights were expanded to the whole area of the prairie provinces. $^{14}$

As Woodward and others have reported, courts have created the view that the drafters of the NRTA intended to merge and consolidate treaty hunting rights in the provinces of Manitoba, Saskatchewan, and Alberta. According to this analysis, the right to hunt has been extended beyond specific treaty territory boundaries. Specifically, the view that the NRTA was intended to merge and consolidate treaty rights was extended by the Supreme Court of Canada in $R$.

One of the few historical studies is found in Chester Martin, Dominion Lands Policy, Lewis H. Thomas, ed., reprint (Toronto: McLelland and Stewart, 1973); see especially ibid. at 204-26. For a sense of the management of Dominion Land in western Canada prior to the transfer, see Kirk N. Lambrecht, The Administration of Dominion Lands, 1870-1930 (Regina: Canadian Plains Research Centre, 1991). Cited as the Constitution Act, 1867, (U.K.), 30 \& 31 Vict., c. 3, reprinted in R.S.C. 1985, App. II, No. 5 .

13. The published literature on the NRTA includes: Gerard V. La Forest, Natural Resources and Public Property under the Canadian Constitution (Toronto: University of Toronto Press, 1969) at 35-45; Robert irwin, "A Clear Intention to Effect Such a Modification": The NRTA and Treaty Hunting and Fishing Rights" (2000) 13 Native St. Rev. 47; and Kent McNeil, Indian Hunting, Trapping And Fishing Rights In The Prairie Provinces of Canada (Saskatoon: University of Saskatchewan Native Law Centre, 1983) who, at 20-37, explored the meaning of the "game laws paragraph" by considering the reported cases that have interpreted para. 12 with respect to impact on jurisdiction, the definitions of "Indians of the Province," its non-effect with respect to fisheries, and the rights of access to lands for hunting. Jack Woodward, Native Law (Toronto: Carswell, 1989) at 319. 
v. Horseman. ${ }^{15}$ In the Court's judgment, original commercial treaty rights had been exchanged for larger subsistence hunting rights by means of a substantial quid pro quo. This finding was confirmed in R.v. Badger.$^{16}$ Intellectual deference to these decisions has meant that the deliberate modification in 1929 of a treaty is regarded as an historical fact.

Current controversies concerning Indian livelihood and the NRTA have not really been assisted by the published literature. In some of the leading texts or common authorities on the law and Aboriginal people, the NRTA has been ignored or handled in a laconic and formalistic manner. ${ }^{17}$ The Indian livelihood provision of the NRTA has not generated nearly the same level of legal and historical analysis as have treaties or the Royal Proclamation of $1763 .^{18}$ Most discussions have been content to uncritically reiterate the case law. ${ }^{19}$

To pursue the question of statutory intent by accurately reconstructing the historical context (as the Supreme Court now seeks to do), it is essential to make use of a variety of archival records. These documents, along with official published primary sources, are the only sources of information available from which to reconstruct the tedious details of the negotiations. The notion that documents speak for themselves is a common, but intellectually insufficient foundation for reconstructing historical processes. ${ }^{20}$ Reliance solely on plain text of the final version of a provision in a negotiated agreement, especially one that lacks elegant wording and that attempts to deal with contentious issues involving Aboriginal interests, is prone to creating flawed interpretations. Any consideration of records indicating intent must

17 The NRTA received no attention in Shin Imai, Katherine Logan \& Gary Stein, Aboriginal Law Handbook (Scarborough: Carswell, 1993). Thus, their discussion of the source of hunting, fishing and trapping rights is incomplete and the important issues raised in Horseman were relegated to a few crude generalizations in the footnotes. The lack of analysis is regrettable given the fact that this judgment has some important implications for commercial rights in the Treaty 9 territory. Terse comments were offered in a later edition (see Shin Imai, Aboriginal Law Handbook, 2d ed. (Scarborough: Carswell, 1999) at 49-50,53,87 and 93. The NRTA and the constituitive provincial agreements were completely omitted from Consolidated Native Law Statutes, Regulations and Treaties (Scarborough: Carswell, 1994). Peter A. Cumming \& Neil H. Mickenberg, eds., in Native Rights in Canada (Toronto: General Publishing, 1972) at 211-14 referred to the NRTA in the context of Native hunting rights and provide a useful discussion and analysis of early cases concerning the right of access and provincial legislative attempts to modify this hunting right. The legal literature on the provisions of para. 12 of the NRTA is often limited to reproducing cases in which particular interpretations have been made. Norman $\mathrm{K}$. Zlotkin considered the effect of the Constitution Act, 1930, supra note 6 on treaty hunting and fishing rights by selecting judicial interpretations of federal and provincial laws ("Post-Confederation Treaties" in Bradford W. Morse, ed., Aboriginal Peoples And The Law (Ottawa: Carleton University Press, 1985) 272). Thomas Isaac, in Aboriginal Law: Cases, Materials And Commentary (Saskatoon: Purich Publishing, 1995), selected part of the Horseman judgment and briefly traced several judicial interpretations concerning NRTA hunting rights; however, Isaac did not take note of the problem of the definition of Indian in the NRTA. Leonard Ian Rotman, in Parallel Paths: Fiduciary Doctrine and the Crown-Native Relationship in Canada (Toronto: University of Toronto Press, 1996) at 71 noted that the fiduciary relationship was indicated in the reserve lands clause of the NRTA. Reprinted in R.S.C. 1985, App. II, No. I

11) Similarly, legal analysis maybe disregarded. Relevant court cases are ignored and the NRTA is passed over in Richard T. Price \& Shirleen Smith, "Treaty 8 and Traditional Livelihoods: Historical and Contemporary Perspectives" (1993-1994) 9 Native St. Rev. 51; for the NRTA, see Price \& Smith, ibid. at 62 and 67-68.

21 It is not possible to get into these issues here, but for a helpful source, see E.H. Carr, What is History (London: Penguin Books, 1987) 7-30 ("The Historian and his Facts"). 
also appreciate the general context in which the NRTA came about and from which the specifics of the livelihood rights paragraph can be grasped. The amendment to our Constitution in 1930 by the Imperial Parliament entailed the enactment of agreements that were negotiated by the federal and the provincial governments of Manitoba, Alberta, and Saskatchewan. When the bills that scheduled the agreements were considered in the Canadian House of Commons, no effective scope to alter or improve the agreements existed. Thus, the circumstances surrounding the agreements is vital. We must appreciate, for example, that the wording of para. 12 was not crafted in one sitting, but instead its development can be traced over several years. The provision, like the entire agreement, was negotiated by "two" parties - in fact, by four governments. ${ }^{21}$ Politically, however, the three provinces played unequal roles in shaping the agreement. Furthermore, the Dominion government was not a single entity for the purpose of creating an agreement; officials from several departments were involved, along with the Prime Minister and several ministers. A reconstruction of this process must take notice of the standpoint of various participants, but also allow for the possibility that such individual standpoints might vary from what may have been expected. Clearly, earlier drafts of this provision hold insights about intent. Rather than assume a priori that these records are inherently antithetical to any particular interest or to a given line of reasoning, an historical approach attempts to discern how things came about, and within reason, why things came into being.

No paucity of archival records can account for the hidden historical significance of the Constitution Act, 1930. Along with provincial documents, records from the Hudson's Bay Company, the Department of Indian Affairs and the federal Justice Department combine to complete a reconstruction in a manner that has not hitherto been attempted. Crucial and authoritative evidence with respect to the problem of ascertaining the intent of the Indian livelihood rights clause is derived from Justice Department opinions. The records of the Department of the Interior, and the Department of Marine and Fisheries, also available in the National Archives, as well as provincial records from the Manitoba Department of Natural Resources and the papers of Manitoba Premier John Bracken have been consulted. Even the private diaries of Prime Minister William Lyon Mackenzie King ${ }^{22}$ have assisted with understanding the political and legislative context in which the NRTA was achieved. Because the agreements reached in 1929 and 1930 needed the approval of the Imperial Parliament, the involvement of the Department of External Affairs in turn created a repository of records relating to the transfer. ${ }^{23}$ An historical reconstruction of the drafting of the livelihood rights

See supra notes 6-7 and accompanying text.

King's diaries are an interesting read in themselves, as are his credentials: William Lyon Mackenzie King, C.M.G. (1906), B.A. (1895), LL. B. (1896) University of Toronto; Post graduate Course Fellow in Political Economy, University of Chicago (1896-1897): Fellow in Political Science. Harvard (18971900); M.A., Harvard University (1898); Ph.D., Harvard (1909); Deputy Minister of Labour (19001908); M.P. North Waterloo (1908-1911). Prince (1919-1921), North York (1921-1925), Prince Albert (1926); Minister of Labour (1909-1911) in Laurier administration; selected leader of Liberal Party of Canada (August 1919); Leader of the Opposition, House of Commons (1919-1921). Prime Minister 29 December 1921 until 28 June 1926, and 25 September 1926 until 7 August 1930; appointed Imperial Privy Council (1922), as cited in A.L. Normandin, ed., The Canadian Parliamentary Guide (Ottawa: Mortimer, 1931) at 175.

23. External Affairs had knowledge of the development of the agreements in advance of its role in transmitting them to the Imperial Parliament. Under-Secretary of State for External Affairs, Oscar Douglas Skelton participated in talks concerning the agreement; for example, in November 1924. Skelton accompanied Mackenzie King to a meeting with Alberta s Premier Greenfield and Attorney 
paragraph of the NRTA, which draws on so many archival sources, is necessarily detailed. It would be much easier to gloss over some of the ambiguity and messy details and simply to select the pieces of historical evidence that best support an interest-based argument. In Blais, more exposure to the historical records occurred, but it is my initial opinion that the historical process has been crudely represented and that perhaps, causal aspects have been historically misapprehended. However, the intersection of law and history in treaty and Aboriginal rights disputes entails many interests from which real outcomes ensue - all of which deserve rigorous consideration.

Another approach, followed by the appellant in Blais, is simply to declare that contentious issues are a matter of law, not history. The appellant's factum beseeched: "the meaning of the term 'Indian' in the NRTA is a question of law for the Court to decide, and not a question of fact for the acceptance by the Court of an expert opinion on the issue." ${ }^{24}$ This is a very understandable reaction to mounds of archival documents. As this article will demonstrate, it might be rather inconvenient or even perplexing to follow through on what the Supreme Court now requires: "The analysis must be anchored in the historical context of the provision." ${ }^{25} \mathrm{Had}$ the courts initially interpreted the expression "Indians of the Province" in a plain, simple, and natural manner, and not unwittingly read into para. 12 a secondary and more limited meaning, then the more recent recourse to the historical circumstances might not have been necessary. Or, had the Supreme Court and other courts had employed the definition of Indians accepted in Blais (Treaty Indians and Indian Act Indians only) from the start, the supposed linkages between the NRTA and treaties could not have been articulated. Clearly, a recognition of the Metis as Indians of the Province for the purposes of the NRTA challenges the treaty right jurisprudence on para. 12 .

The NRTA also provides for Indian reserves and reversionary interests (paras. 10 and 11 ); however, these issues cannot be considered here ${ }^{26}$ Moreover, para. 1, which transfers public lands generally to the provinces "subject to any trusts existing in respect thereof, and to any interest other than that of the Crown in the same," between treaty and Aboriginal rights and the Constitution Act, 1930. For example, would an unextinguished Aboriginal harvesting right constitute a non-Crown interest in Crown lands for the purposes of para. 1 ? Not all of these issues can be purposefully pursued in this article, but the broad examination of archival records presented here provides a foundation for further analysis.

The structure of this article essentially follows the chronological history of the agreements' development before examining the key decisions arising from litigation of hunting rights. Part 1 of this article provides an overview of the development of the NRTA, a detailed recounting of the 1926 and 1929 negotiations, followed by a comparison and explanation of the changes

General Brownlee (King Diaries, supra note 1 (19 November 1924))

24 Blais, supra note 3 (factum of the Appellant at para. 82) [emphasis in original]; similarly at para. 56 of the factum, Counsel for the Applicant Lionel Chartrand also pleaded, "it is inappropriate to place significant weight on the evidence of expert witnesses as to the intent of the drafters of the NRTA" (ibid.) [Blais Appellant factum]

25. Blais Appellant factum, ibid. at para. 40.

26 Paragraphs 11-12 in the Manitoba agreement, supra note 4.

$27 \quad$ NRTA, supra note 6 . 
in text with respect to the Indian livelihood rights paragraph. Since fishing is vital to Aboriginal livelihood, the provision transferring fishing rights to the Prairie Provinces will also be examined ${ }^{28}$ The drafting of the livelihood rights paragraph can best be appreciated by first considering the political and legislative history of the NRTA. An agreement reached in 1926 for transferring the natural resources to Alberta served as a political and legislative precedence for the 1929 agreements. It has a particular significance for understanding the intention of the livelihood rights paragraph, even though its existence is largely unknown. Although the agreements for the three provinces are very similar, and the wording of the Indian livelihood rights is identical, the process by which each particular agreement was created is somewhat different.

Part 2 will focus on the legal understandings of para. 12 of the NRTA. Shortly after the NRTA came into force, questions arose concerning the interpretation of para. 12. The direction about the meaning of "Indians of the Province" provided by the federal Department of Justice to the Province of Alberta is cogent and merits close examination. The resulting historical analysis is then brought to bare on the accepted judicial understandings of the existing livelihood rights of prairie First Nations. Whatever historical inaccuracies may have been incorporated into the reasoning of cases such as Horseman ${ }^{29}$ and Badger $^{30} \mathrm{I}$ appreciate that courts are confined by the evidence provided. If the facts concerning the development of the Constitution Act, 1930 are rendered obscure, then other means must be found to devise interpretations. Fundamentally, and with all due respect, I take issue with the conclusions and the treaty rights reasoning of the Supreme Court of Canada on what is said and believed to have transpired as a matter of historical fact. This lengthy and critical consideration of Supreme Court of Canada reasoning on the meaning of the NRTA Indian livelihood right will prove conclusively to some readers that attempting to employ historical evidence to a rights controversy after the issues have been legally determined is an exercise in futility.

At the very least, this article offers a corrective view of the NRTA. Consistent with our continuing efforts as a nation to devise the means and structures that will allow Indigenous and settlers' societies to share space more equitably, some seven decades after land and resources were transferred to the provinces, controversy and ambiguity remain.

\section{The Political and Legislative Processes OF TRANSFERRING RESOURCES}

The fact that in 1870, Manitoba (along with Saskatchewan and Alberta in 1905) did not obtain control over public lands was a matter of populist grievance. ${ }^{31}$ With respect to Manitoba, Professor Chester Martin ${ }^{32}$ expressed this view in no uncertain terms in 1920:

Paragraph 10 in the Manitoba agreement, supra note 4.

Supra note 15.

Supra note 16.

Consider the pamphlet by W. Everard Edmonds, "The Natural Resource Question: A Plea for the Completion of Alberta's Status as a Province of Canada" (Edmonton: n.p., 1922).

Chester Martin, F.R.S.C., B.A. (University of New Brunswick), M.A. (Oxford), LL.D. (University of Manitoba) at the Public Archives of Canada (1908-09); Head of the Department of History, University of Manitoba (1909-1929); Professor and Head of Department of History, University of Toronto (from 1929); Counsel for Resources Commission (1928-29); and President Canadian Historical Association (1928), as cited in B.M. Greene, ed.. Who's Who in Canada: 1949-50, vol. 38 (Toronto: International 
This province, therefore, has the unenviable distinction among the provinces of Canada and the self-governing Dominions of the Empire, not only of having been born into 'colonial' subordination in respect of public lands by provisions in the Manitoba Act contravening every recorded expression of the demands of the inhabitants of the country, but [also] of having the serf's collar riveted, even in adult manhood, by statutory re-enactment in the hardest and most uncompromising terms. ${ }^{33}$

Martin provided a scholarly foundation when he assisted the Manitoba government with its claim, but he went so far as note that " $[\mathrm{t}]$ he rest of Canada, however, in exasperation at the deeds of a few hundred Métis in 1870 at the Red River Settlement, has penalized the rest of the province for fifty years." 34 Instead of blaming Louis Riel's provisional government, it is generally acknowledged that a free homestead land policy and the ability to allocate of vast amounts of land to railroad companies was necessary for the Dominion government to promote immigration, settlement, and development of the Manitoba and the Northwest. Thus public lands were for the purposes of the Dominion, before and after self-governing powers were assumed with the creation of provinces. Federal subsidies in lieu of these administrative powers did not, especially in Manitoba, constrain this issue. Moreover, the need for a free homestead policy could not justify the Dominion retaining the resources of a large portion of the Keewatin District, which had been added to Manitoba in 1912.

Essentially, the political issue entailed the transfer of natural resources to provincial authority and the question of compensation from the Dominion government to provincial governments for lost revenue as a consequence of the lack of provincial "ownership" of lands and resources. Prairie premiers actively pursed this grievance, especially from 1913 on. Premiers Walter Scott, R.P. Roblin ${ }^{35}$ and Arthur L. Sifton wrote Prime Minister R.L. Borden $^{36}$ in 1913 requesting that: "...all lands remaining within the boundaries of the respective Provinces, with all natural resources included, be transferred to the said Provinces, the Provinces accepting respectively the responsibility of administering the same." 37 The issue of compensation eluded a ready remedy because the Dominion government would not

Press, 1950) at 1327

"3 Chester Martin, "The Natural Resources Question": The Historical Basis of Provincial Claims (Winnipeg: Philip Purcell, King's Printer for the Province of Manitoba, 1920) at 50.

.4 Ibid. at 45; at 50, Martin concluded: "[ $\mathrm{t}]$ he animosities of the Riel Insurrection and the motives under which provincial status was sought and secured in the Manitoba Act long inspired an unenviable and rather undiscriminating prejudice against this province."

3 Rodmond Palen Roblin, K.C.M.G. (1913); Conservative. elected to the Manitoba legislature in 1888: leader of opposition, formed government (29 October 1900); served as Premier. President of Council, Commissioner of Railways, Minister of Agriculture (1900); re-elected to the legislature 1900, 1903. 1907, 1910 and 1914, as cited in Ernest J. Chambers, ed., The Canadian Parliamentary Guide: $19 / 5$ (Ottawa: Ernest John Chambers, 1915) at 437.

3. Robert Laird Borden. G.C.M.G. (1913), K.C.: called to the Bar in 1878: headed the law firm Borden. Ritchie and Chisholm (Halifax); elected to House of Commons. 1896 and re-elected 1900, 1905, 1908. 1911; elected leader of the Opposition (6 February 1901): became Prime Minister following the defeat of Wilfrid Laurie government on 10 October 1911: summoned to Imperial Privy Council (I January 1912) as cited in Chambers. ed.. ibid. at 111-12.

37 Letter from Premiers Scott. Roblin, and Sifton to Prime Minister Borden (ca. 22 December 1913). Winnipeg. Archives of Manitoba [AM], public records of the Ministry of Natural Resources (RC $; 17$. Al, file 2). These records were formerly referred to as Provincial Archives of Manitoba [PAM] and changes to the catalogue system to these records generates a disconnect between the two systems. 
agree to both the transfer of natural resources and a continuation of federal subsidies. ${ }^{38}$ Given that most of the land alienated during the Dominion era was granted as free homesteads to settlers or as grants to railway companies, on what basis would compensation be calculated? Moreover, in the early 1920s, the Dominion government maintained that any agreement concerning the transfer of resources would have to be acceptable to the other provinces. ${ }^{39}$ Acceptance by other provinces of the transfer would be contingent upon the amount of compensation paid to the Prairie Provinces. The Maritime Provinces of New Brunswick and Nova Scotia argued that they had proprietary interests in western lands, since the Dominion of Canada had purchased Rupertsland and the Northwestern Territory in 1870 for $£ 300,000 .^{40}$ These provinces were concerned about land and resource issues because, in contrast to Ontario and Quebec, their provincial territories did not expand after 1867. In terms of reconciling various agendas of provincial and Dominion governments, the NRTA as a constitutional process was as involved and as complicated as other changes to the Constitution. ${ }^{41}$ Given this drawn-out process and matrix of contending interests it would be wrong to assume that the drafting of the amendment to the Constitution Act, $1867^{42}$ was simple and straightforward or that it was pieced together accidentally.

Manitoba's grievance was older than that of Saskatchewan and Alberta, whose claims to compensation for the loss of beneficial interest could only go back to 1905, when these two provinces were created as self-governing jurisdictions. Manitoban politicians demonstrated more resolve than the other two Prairie Provinces, especially Alberta ${ }^{43}$ The Province of Manitoba argued:

[w]e beg to submit that any permanent settlement of the Natural Resources Question must be based upon the ample recognition on [the] part of the Dominion [of] the inherent British rights of the Prairie Provinces to their natural resources as from the date of provincial organization or responsible government; the restoration of full provincial beneficial control of these which remain unalienated, and compensation upon a fiduciary basis for those which have been alienated by Canada for the purpose of the Dominion: ${ }^{44}$

The creation of the Provinces of Alberta and Saskatchewan and the northward extension of Manitoba's borders in 1912 had established in perpetuity per capita grants from the Dominion government in lieu of natural resources. In 1913, the Prairie Provinces were seeking the transfer of natural resources and continuation of the per capita grants. Even at this late date, the Dominion government was still concerned that provincial control over natural resources might affect homestead policies and a continued flow of immigration.

On the early negotiations, see J. Castell Hopkins, The Canadian Annual Review of Public Affairs: 1921 (Toronto: Canadian Review Company, 1922) at 740-41, 837-38; and a file on the correspondence that occurred during the Meighen government (Public records of the department of External Affairs, Ottawa, NAC (RG 25, vol. 1321, file 650)).

Rupert's Land and North-Western Territory Enactment No. 3 made by Order-in-Council (23 June 1870), online: Department of Justice Canada <http://canada.justice.gc.ca/en/ps/const/loireg/plt31.html>.

In the House of Commons, Mackenzie King's speech recounted the history of the natural resource question and how the various provincial concerns had been balanced in the process (House of Commons Debates (30 April 1930) at 1602-11). Supra note 12 .

4. Following a conference between the prairie Premiers and the Prime Minister, in which Manitoba's proposal was rejected by the Meighen government, Alberta Premier Charles Stewart wrote to Meighen indicating a willingness by Alberta to negotiate on the terms offered by Meighen (Letter, Stewart to Meighen (6 June 1921), Ottawa, NAC (RG 25, vol. 1321, file 650))

it Letter. Meighen to Norris quoting Memorandum from Manitoba, Winnipeg, AM (RG 17, Al, file 2). The correspondence between Meighen and Norris can be found in Ottawa. NAC (RG 25. ibid.) 
Thus, Manitoba had advanced a constitutional principle as a means of settling the issue and objected to any arbitrary settlement that might ensue from the partial retention of inperpetuity subsidies in lieu of lands. Manitoba sought an accounting of the financial results on a fiduciary basis, not a simple compilation of debits and credits. Premier T.C. Norris ${ }^{45}$ argued: "[w]hat we have in mind is the kind of accounting due from a trustee to his beneficiary. Such accounting would start out with the admission that Manitoba was as of right, and in the light of all British precedents, entitled to her public domain since the establishment here of responsible government." 46 Norris would not give up the federal subsidy in lieu of lands, unless the Dominion government would agree to an accounting based on fiduciary principle. ${ }^{47}$ In 1922, Prime Minister William Lyon Mackenzie King suggested that a quick settlement of the resource issue could be made if the Prairie Provinces recognized that whatever revenues the Dominion government received were balanced by expenditures, but that nonetheless, he would agree to a binding tribunal that would consider the accounting of compensation. ${ }^{48}$ Manitoba agreed to the idea of a tribunal to consider the question of compensation, but rejected the idea that balancing the receipts and expenditures from Crown lands could be an acceptable approach to compensation. ${ }^{49}$

Conferences, sincere promises of a speedy settlement, research, interviews, and correspondence continued through the 1920s. ${ }^{50}$ Following a conference in Ottawa on 14 November 1922 between Prime Minister Mackenzie King and prairie Premiers John Bracken (Manitoba), ${ }^{51}$ Charles Dunning (Saskatchewan), ${ }^{52}$ and Herbert Greenfield (Alberta), ${ }^{53}$ along with several federal and provincial cabinet ministers, in which the terms offered by the Dominion government were found unsatisfactory, the provinces pursued negotiations separately. ${ }^{54}$ In several throne speeches, Dominion governments had promised to transfer

Tobias C. Norris, elected to Manitoba legislature (1896, 1899, 1907, 1910, 1914, 1920, 1922, 1925. 1927); Premier of Manitoba (May 1915 to August 1922), as cited in B.M. Greene, ed., Who s Who in Canada: 1934-35, vol. 23 (Toronto: International Press, 1935) at 1626.

46. Letter, Norris to Meighen (10 March 1921), Winnipeg, AM (RG 17, Al, file 2)

47 Meighen did not agree to compensation based on a fiduciary principle as this could make the Dominion government responsible for moneys that it should have received and not just what it actually received. He suggested that this could mean that Canada would be responsible for the sale value of homestead lands. Homestead lands were not sold and were essentially free. Such a land policy was designed to encourage immigration and settlement. Thus, the Dominion had not collected revenue from the agricultural lands anywhere near the theoretical value of the homestead lands. Letter, Mackenzie King to Norris (20 February 1922), Winnipeg, AM (RG 17, Al, file 2).

4) For discussion of tribunal options, see e.g. King Diaries, supra note 1 (3 July 1928).

51) A series of lengthy memoranda concerning the financial questions stemming from the proposals made by the Prairie Provinces were prepared in 1921 by John A. Reid for Prime Minister Arthur Meighen (copy found in Papers of John Bracken, Winnipeg, AM (G550, file 232))

\$I John Bracken, B.S.A. (University of Illinois); LL.D.; professor University of Saskatchewan (19101920); elected to Manitoba legislature and premier in 1922 and re-elected in 1927 as cited in A.L. Normandin, ed., The Canadian Parliamentary Guide: 1930 (Ottawa: Mortimer, 1930) at 403; and B.M. Greene, ed., Who's Who in Canada: 1949-50, vol. 38 (Toronto: International Press, 1950) at 22.

32 Charles Avery Dunning, P.C., Liberal; appointed Saskatchewan Provincial Treasure (20 October 1916): Minister of Railways (20 October 1917); Minister of Telephones (16 May 1918); Minister of Agriculture (15 February 1919); became Premier (5 April 1922); appointed federal Minister of Railways and Canals (20 February 1926); elected MP in 1926; and appointed Minister of Finance (26 November 1929), as cited in A.L. Normandin, supra note 51 at 155-56.

5: Herbert Greenfield, Vice-president United Farmers of Alberta (1918-1921); and Premier of Alberta (1921-1925). as cited in Greene, supra note 51 at 1335.

it J. Castell Hopkins, The Canadian Annual Review' of Public Affairs: 1922 (Toronto: Canadian Review Company. 1923) at 221-22 and 574-75 
resources to the Prairie Provinces. ${ }^{55}$ The transfer of natural resources was turned into a constitutional issue that would only be resolved after customary and careful plodding by Canadian officials. But for the Prairie Provinces, it defined an unequal presence in the confederation. On the practical level, Dominion control over Manitoba public lands meant that provincial authorities did not have a share in revenue stemming from a beneficial interest in lands and resources or the ability to set policies for the development of lands and resources. In the abstract, Crown ownership was not the issue, but with jurisdiction and administration came the beneficial interest. An official understanding between the Manitoba and Dominion governments on how to resolve the natural resources issue was made on 21 April 1922. ${ }^{56}$ In this agreement, the Dominion government recognized: the need for adjustments between the Dominion government and the Prairie Provinces; that the Prairie Provinces would be placed in a position of equality with other provinces; that an agreement would be negotiated subject to ratification by Parliament and the Legislatures; that failure to negotiate an agreement would refer the dispute to arbitration; and that awards made by arbitration would be ratified by the Manitoba legislature and the Dominion parliament. ${ }^{57}$ Eventually, this understanding proved to guide the process for resolving the "natural resources question." However, in 1924, serious negotiations between Alberta and the Dominion commenced. ${ }^{58}$ Yet, only by January 1926 did the governments of Alberta and Canada reach a separate agreement for transferring resources, but with very limited compensation. ${ }^{59}$ This agreement was not confirmed by federal statute because the Alberta legislature made changes to the school lands trust fund clause. ${ }^{60}$ Progress on resolving this issue also slowed when the Mackenzie King government lost a non-confidence motion in June 1926 and, after a short-lived Conservative government lead by former Prime Minister Meighen, a general election was held in September in which Mackenzie King was reelected. ${ }^{61}$

Following the collapse of the 1926 Alberta agreement, the Province of Manitoba effectively played a more active role in negotiations with the Dominion. Essentially, the reengagement of Alberta had to wait for a reference to the Supreme Court on the constitutional validity of s. 17 of the Alberta Act which was heard on 7 March 1927. Neither Saskatchewan

See e.g. King Diaries, supra note 1 (9 January 1926) and (26 January 1929).

House of Commons Debates (21 April 1922) at 1017-18.

Ibid. at 1018.

Mackenzie King recorded an interview he held with his cabinet ministers and Alberta Premier Herbert Greenfield (King Diaries, supra note 1 (3 January 1924)).

The federal government's position was put to Alberta in November 1924 and by December 1924 Alberta had accepted the terms (King Diaries, ibid. (24 November and 18 December 1924)). On 4 January 1924, the Prime Minister and Brownlee agreed to include the return of the natural resources of Alberta in the upcoming throne speech (King Diaries, ibid. (4 January 1924)). Mackenzie King recorded the signing of this agreement: "At noon Brownlee of Alberta \& Smith a member of his Gov"t - a conservative - came in with Lapointe \& Mr. Stewart \& signed the agreements for transfer of the Natural resources to Alberta"( King Diaries, ibid. (9 January 1926)).

For a terse summary of the school lands issue in Alberta legislature, see J. Castell Hopkins, ed., The Canadian Annual Review of Public Affairs: 1925-26 (Toronto: Canadian Review Company, 1926) at 495-97. A newspaper reported that a impasse had been reached and that the transfer "is in danger of being shattered on the rocks of the separate school issue" ("Dominion Bargain With Alberta May Not Be Concluded" Montreal Gazette (12 May 1926), reproduced in Ottawa, NAC (RG 25, vol. 797, file 507)).

Arthur Meighen was appointed Prime Minister on 26 June 1926 but his conservative government was defeated in the general election 14 September 1926 
nor Alberta filed a factum and a special counsel had to be appointed to represent all those opposed to the view of the Attorney-General of Canada. On 20 April 1927, the unanimous Court held that s. 17 of The Alberta Act ${ }^{62}$ was not ultra vires of the Parliament of Canada. ${ }^{63}$ Nonetheless, Canada applied for a special appeal to Judicial Committee of the Privy Council; however, by mid-August the Minister of Justice had been unable to arrange a means for an appeal. ${ }^{64}$ In early January 1928 , discussions with Alberta were renewed. ${ }^{65}$ Manitoba Premier Bracken had rejected the terms of the 1926 Alberta agreement, stating that "the terms which have been made with the Province of Alberta are not, and in our opinion never can be, acceptable to the Province of Manitoba." ${ }^{, 60}$ After allowing several years to pass, Bracken proposed that it was time to submit the question to arbitration, as provided by the understanding of April 1922. ${ }^{67} \mathrm{He}$ recommended that the Judicial Committee of His Majesty's Privy Council serve as the tribunal. Needless to say, the arbitration did not go to the Privy Council. A conference was held on 3 and 4 July 1928 in Ottawa, ${ }^{68}$ which began by reviewing correspondence on the issue, but in his personal diary, Mackenzie King divulged: "I confess I felt ashamed of our side of the record, the continuous procrastination." At this conference, the Dominion and Manitoba governments agreed to use a Royal Commission, a suggestion made by Justice Minister Ernest Lapointe, ${ }^{70}$ as "the method and basis of settlement of the question of the administration and control of the natural resources."7l The question of compensation was not essentially a legal question that could be best put to the Privy Council. Mackenzie King wanted a public inquiry that could educate public opinion

1905, 4-5 Edw. VII, c. 3, reprinted in S.C. 1905, c. 3 [Alberta Act].

Reference re: Alberta Act, s. 17. [1927] S.C.R. 364.

For a terse summary of this dispute, see Memorandum for Acting Minister of Justice (14 September 1931). Ottawa, NAC (RG 13, vol. 2520, file C-1008).

On 13 January 1928, Mackenzie King had an interview with Brownlee (King Diaries, supra note 1 (13 January 1928)).

Letter, Bracken to Mackenzie King (13 January 1927), Winnipeg, AM (RG 17, Al, file 2) [Bracken letter]. See also House of Commons Debates (11 February 1929) at 35. The 1926 Alberta agreement provided little compensation for the loss of provincial beneficial interests.

Bracken letter, ibid.

See King Diaries, supra note 1 (3 July 1928); and infra note 69.

Ibid. A record of the meeting indicated the participants at the meeting on 3 July 1928 included: for Canada, Prime Minister Mackenzie King, James Robb (Minister of Finance). Ernest Lapointe (Minister of Justice), Charles Avery Dunning (Minster of Railways). Charles Stewart (Minister of the Interior). and Peter J. Veniot (Postmaster General), and O.D. Skelton (Undersecretary of State for External Affairs); and, for Manitoba, Premier Bracken, W.I. Major (Attorney General) and R.A. Hoey (Minister of Education), and Chester Martin (Natural Resources Conference with Province of Manitoba (3 July 1928), Ottawa, NAC (RG 25, vol. 797, file 507)).

Ernest Lapointe, K.C., B.A. (1895), LL.B. (1898) Laval University; called to the Bar (1898); K.C. (1908); Member of Parliament for Kamouraska (1904-1919); and for Quebec East (1919); Minister of Marine and Fisheries (29 December 1921); Minister of Justice (January 1924), as cited in Greene, supra note 45 at 1232 .

Privy Council, Order-in-Council 1258 ( 1 August 1928) copy found in Hon. W.F.A. Turgeon. Chairman. Hon. T.A. Crerar \& Charles M. Bowman, Report Of The Royal Commission On The Transfer Of The Natural Resources of Manitoba (Ottawa: F.A. Acland, 1929) at 5 [Manitoba Report]. Turgeon was a Justice of the Saskatchewan Court of Appeal and former Attorney General of Saskatchewan. Crerar had been leader of the Progressive Party and a cabinet minister in the union government. Bowman was Chairman of the Board of Mutual Life Assurance Company of Canada. See also J.D. Mochoruk, "The Political Economy of Northern Development: Governments and Capital Among Manitoba's Resource Frontier, 1870-1930" (Winnipeg: unpublished Ph.D. dissertation, University of Manitoba, 1992) at 514. 
and so that the findings could be reviewed by Parliament and the legislature. ${ }^{72}$ The shift to a Royal Commission was certainly a more amicable process than a binding arbitration tribunal, but it also signalled that the Dominion government was prepared to extend the period of subsidies. As a process, a Royal Commission would provide credibility that would limit the criticism of other provinces claiming to have a stake in the transfer. In particular, this Royal Commission was intended to deal with the issue of compensation and subsidies. (The specifics of compensation for Alberta and Saskatchewan were dealt with after the agreements had been enacted, ${ }^{73}$ whereas Manitoba and the Dominion reached an understanding on compensation during the negotiations associated with the Royal Commission. ${ }^{74}$ ) With respect to Manitoba's resources, an Order-in-Council of 1 August 1928 provided the means for dealing with the financial issues. Manitoba's position on adopting constitutional principles for settling the dispute had been accepted: "The Province of Manitoba to be placed in a position of equality with the other provinces of Confederation with respect to the administration and control of its natural resources, as from its entrance into Confederation in 1870." ${ }^{, 75}$ This Order-in-Council also appointed the commissioners, and gave the commission the power to decide financial and other considerations. After considering the report, both governments would "introduce the necessary legislation to give effect to the financial terms as agreed upon, and to effect the transfer to the province of the unalienated natural resources within its boundaries, subject to any trust existing in respect thereof, and without prejudice to any interest other than that of the Crown in the same."

The work of the Royal Commission on Manitoba Resources was largely concerned with producing a recommendation for financial readjustments that should be made to the Province. The manner in which lands and resources had been alienated was considered by the commissioners. After considering the financial effects of various past policies (subsidies, interest, etcetera), or the "balancing of claims," the commissioners laconically calculated that the precise balance in Manitoba's favour was $\$ 4,584,212.49 .{ }^{77}$ The settlement proposed by the commissioners was not based on fiduciary principles. During a meeting with the commissioners, the representatives for the Province of Manitoba abandoned the demand for compensation based on fiduciary principles and instead asked for a cash payment of $\$ 6,000,000$ and a continuation of the existing subsidies. ${ }^{78}$ Subsidies in perpetuity were also agreed upon and this financial compensation package was certainly less than what would have resulted had compensation been calculated on a fiduciary basis, but a much better

Natural Resources Conference with the Province of Manitoba (3 July 1928) Ottawa, NAC (RG 25, vol. 797, file 507).

Paragraphs 20,21, and 22 in the Alberta agreement, supra note 6 and paras. 21, 22, 23, and 24 in the Saskatchewan agreement, supra note 6.

74 For the Alberta and Saskatchewan commission, see Hon. A.K. Dysart, Hon. T.M. Tweedie \& George

C. McDonald, Report Of The Royal Commission On The Natural Resources Of Alberta (Ottawa: I.O. Patenaude, Printer to the King's Most Excellent Majesty, 1935) [Alberta Report]. Hon. A.K. Dysart (Chairman), Hon. H.V. Bigelow, \& George C. McDonald, Report Of The Royal Commission On The Natural Resources Of Saskatchewan (Ottawa: I.O. Patenaude, 1935) [Saskatchewan Report]. Oliver Master served as Secretary for these commissions.

Manitoba Report, supra note 71 at 5 .

Ibid.

Ibid. at 45

Mochoruk, supra note 71 at 516-17 
settlement than what Alberta had agreed to in $1926 .{ }^{79}$ The Royal Commission for Manitoba Resources officially reported on 30 May 1929, thereby clearing the way for the drafting of the rest of the agreement and, on 26 June 1929, Manitoba and Canada agreed to the recommendations of the Commission. ${ }^{80} \mathrm{~A}$ summary of this meeting recorded:

[i]t was agreed that the drafting of an agreement should be undertaken by the Department of Justice and the Department of the Interior, in consultation with Messrs. Craig and Hudson for the Province [of Manitoba]. This could not be done until Mr. Edwards and Mr. Plaxton of the Department of Justice had returned to Ottawa. $^{81}$

At this meeting, Manitoba indicated a willingness to set aside Indian reserve lands. Apart from the financial compensation to the Prairie Provinces, the Dominion government was obligated to secure the existing land and resource tenures that had been issued by the federal Crown before the transfer to the provinces. The content of the agreement, enforced by concurrent statutes in 1930, outlined some of existing trusts and interests that had come into being since $1870 .^{82}$ Specific non-Crown interests included railroad lands and the large lands granted to the Hudson's Bay Company ${ }^{83}$ With respect to the continuation of subsidies, the Dominion government indicated that it was prepared to employ similar treatment with Saskatchewan and Alberta as it had employed with Manitoba. ${ }^{84}$

While Alberta and Manitoba pursued negotiations differently, both provinces contributed to the agreement with the Dominion. In contrast, the Province of Saskatchewan played

7. Ibid. at 528-29 has suggested that at least $\$ 200,000,000$ would be owed to Manitoba for the loss of land, timber and mineral resources had the fiduciary principle been used to determine compensation. Meeting to consider the report of the Royal Commission for Manitoba Resources of 30 May 1929 (26 June 1920) Ottawa, NAC (RG 25, vol. 797, file 507) included: Mackenzie King, Ernest Lapointe, James Robb, Charles Stewart, W.R. Motherwell, Robert Forke, J.L. Ralston, (Canada); and John Bracken, W.J. Major, A.B Hudson and R.W. Craig (Manitoba). Bracken was advised by Mackenzie King that the report had been printed on 12 June 1929 (Montreal Gazette (27 June 1929), reproduced in Ottawa, NAC (RG 25, vol. 797, file 507)).

xI Memorandum on the transfer of natural resource of Manitoba conference on 26 June 1929 (28 June 1929), Ottawa, NAC (RG 25, vol. 797, file 507). The commission was assisted by A.R. McMaster (Solicitor General) and C.P. Plaxton (Justice) and, for Manitoba, by A.B. Hudson, C.W. Craig, and Professor Chester Martin. Richard Craig, K.C., B.A. (1897), LL.B. (1904) University of Manitoba; called to the Bar (1905); member of Macdonald, Craig, Tarr, Armstrong and Hughes, Macleod and Ross; prosecutor for the City of Winnipeg (1910-1912); K.C. (1916); Member and Bencher Manitoba Law Society; elected Manitoba Legislature (1922); served as Attorney General (8 August 1922-April 1927), as cited in Greene, supra note 32 at 806. Albert Blellock Hudson, K.C., LL.B. (University of Manitoba); called to the Bar 1899; of Hudson, Ormond, Spice and Symington; Bencher of the Law Society; K.C. (1914); elected Manitoba legislature 1914, 1915; Attorney General and Minister for Telephones and Telegraphs (May 1925; resigned November 1917); elected MP (December 1921), as cited in Greene, supra note 45 at 1232. Charles Percy Plaxton, LL.B. (Osgoode Hall), admitted to the Ontario Bar (1915); appointed as clerk. Department of Justice (10 December 1915); appointed Senior Advisory Counsel, Department of Justice (1 April 1922)(Ottawa, NAC (RG 13, vol. 247, file 1920-517. and vol. 270, file 1922-1463)).

*2 See supra note 6 .

8.3 The HBC lands and interests stemmed from the Deed of Surrender (1870) and an agreement approved by Order-in-Council (P.C. 2158) of 19 December 1924

k4 "Manitoba and Ottawa agree on resources" Montreal Gazette (27 June 1929), reproduced in Ottawa, NAC (RG 25, vol. 797, file 507). During the debate in the House on the Alberta agreement (30 April 1930), Mackenzie King read into the record the press statement of 26 June 1929 (House of Commons Debates (30 April 1930) at 1608). 
virtually no role in shaping the general terms of the agreement. In fact, the Manitoba legislature had confirmed the agreement before Saskatchewan had signed its memorandum of agreement with Canada (20 March 1930). ${ }^{85}$ To a certain extent, Saskatchewan was not in a position to participate in negotiations. The election of 26 June 1929 had resulted in a Liberal minority government, lead by Premier James G. Gardiner, that was replaced in September by an informal coalition of conservatives and progressives lead by James Thomas Milton Andersen. ${ }^{86}$ Thus, in terms of working towards an agreement, by the autumn of 1929 , Manitoba and Alberta were well ahead of the new Saskatchewan government.

Nevertheless, Saskatchewan representatives were in Ottawa as agreements were nearing conclusion with Manitoba and Alberta. On 9 December 1929 Mackenzie King noted: "[t]he new Premier of Sask. Anderson is here to make trouble, not to make an agreement"; he lamented the loss of the provincial election to the conservatives: "I feel annoyed at Gardiner [Liberal premier] letting his province get into such hands." 87 The next day, the Prime Minister recorded in his diary:

[f]rom 11 till one we spent the time in Council going over correspondence re Natural Resources in Saskatchewan \& Alberta preparatory to meeting Premier Anderson \& his colleagues which we did in my office at 2:30 this afternoon. He is a rough diamond \& the men with him of a type of low cunning in a way. He had a representative of the U.F. [United Farmers] of Sask as well as his Atty Genl. \& Minister of Public Works. He read a long memorial, craftily drafted $\&$ designed to draw from us a refusal. ${ }^{88}$

At this meeting, the Prime Minister did not respond to Saskatchewan's demands, but simply used the excuse that he could not respond until Lapointe returned. ${ }^{89}$

Apparently, Saskatchewan held to its desire that compensation for losses should not start in 1905 , but should go back to 1870 , and that the Dominion government should be able to account for all land alienations as an administrative trustee. Not surprisingly, the Toronto Mail And Empire (11 December 1929), under the headline "Rebuke is given to Saskatchewan," reported on the outcome of the meeting, indicating that province's representatives were told "the government was not ready to make a decision, and they will return home to-morrow indignant at their treatment and their fruitless quest."90 Saskatchewan's sensitivities did not seem to concern the Prime Minister. After advising his cabinet of the nature of the Manitoba and Alberta agreements (10 December 1929) and, as the long-standing natural resources issue seemed nearly resolved, he confirmed in his diary that he had not expected an agreement with Saskatchewan, but that "[w]e have at least put that province in a position where the present Govt. can do us no harm and only bring reaction upon itself." Moreover, in contrast to western leaders that Mackenzie King respected, such

See supra note 4 (assented to 19 February 1930).

Andersen became premier on 9 September 1929 (see John H. Archer, Saskatchewan: A History (Saskatoon: Western Prairie Producer Books, 1980) at 211-13).

King Diaries, supra note 1 (9 December 1929).

King Diaries, ibid. (10 December 1929).

King Diaries, ibid. (26 June 1929). The fact that Lapointe was not there to participate in the final negotiations or to sign the agreement with the others was not an impediment.

T.H. Blacklock, "Rebuke is given to Saskatchewan" Toronto Mail and Empire (11 December 1929), reproduced in Ottawa, NAC (RG 25, vol. 797, file 507).

King Diaries, supra note 1 (11 December 1929). 
as Premiers John Brownlee ${ }^{92}$ and John Bracken and because his political strategy entailed keeping the federal Progressive and provincial United Farmers governments aligned with the federal Liberal Party, the Premier of Saskatchewan was not held in high regard: "I then went to Can. Club \& listened to a very poor not even mediocre address by Anderson P.M. of Sask., a kindergarten affair delivered as to an audience in a field, a very ordinary man." ${ }^{93}$

Once Manitoba and Alberta settled, there would be little scope for Saskatchewan to retain its position. Indeed, on 13 December 1929, after the Saskatchewan delegation had been sent home, Mackenzie King wrote: "[b]elieve tomorrow we will get agreements signed with both Alberta \& Manitoba transferring their resources \& Saskatchewan placed where it will be difficult for that province not to follow suit." ${ }^{194}$ The federal government's ability to secure agreements was facilitated by a process in which it dealt with each province separately and Mackenzie King was adept at dealing strategically with provincial demands. The Dominion government did not agree to extend the period of compensation to the era before the creation of the province, but Saskatchewan accepted a reference on this issue to the Supreme Court. ${ }^{95}$

Not without reason would Prime Minister Mackenzie King boast, "[t]his will be a memorable day in the history of Canada" afternoon the agreement between the Dominion and Manitoba transferring to the latter province its Natural Resources was signed, and within the next half hour the agreement with Alberta. Both documents were signed in the Council Chamber." ${ }^{\text {97 }}$ While the Prairie Provinces were acquiring an improved position in the federation, back in 1928 King had pragmatically mussed: "[i]t is a mistake for Ottawa to be controlling \& administrating western lands, \& it is a losing \& costly business as it stands and we should get rid of it all just as soon as we can." ${ }^{\text {"98 }}$ The outcome of Mackenzie King's negotiations was an achievement that had alluded Conservative Prime Ministers Borden and Meighen and it represented an intricate constitutional remedy for historically-determined inequity that had to be fashioned within the

92 John Edward Brownlee, K.C., B.A. (Toronto University), LL.B. (University of Calgary), LL.D. (University of Alberta); Attorney General of Alberta (1921-1924); Premier of Alberta (1924-1934); leader of the United Farmers of Alberta; practiced law with Brownlee and Brownlee, as cited in Greene, supra note 32 at 541 .

13. King Diaries, supra note 1 (11 December 1929). After the Manitoba and Alberta agreements had been signed, Mackenzie King wrote: "[i]t is interesting that these agreements [should] have been made with Progressive governments. It should help bring closer together Lib \& Prog forces" (King Diaries (14 December 1929)). Similarly, Mackenzie King stated in the House of Commons: "I have stated, in different parts of this country over and over again, that I looked upon the Progressive party and the Labour party as advanced wings of the Liberal party; that their policies were fundamentally Liberal policies" (House of Commons Debates (10 February 1930) at 32). King Diaries, ibid. (13 December 1929).

The Supreme Court held that after 1870 the lands were vested in the right of the Dominion. The decision on the reference on Saskatchewan lands was handed down on 3 February 1931 ("Supreme Court Favors Ottawa On Land Appeal" Montreal Gazette (4 February 1931), reproduced in Ottawa, NAC (RG 25, vol. 797, file 507)).

King Diaries, supra note 1 (14 December 1929).

King Diaries, ibid. (14 December 1929). The Manitoba agreement was probably closer to completion than the Alberta agreement; Bracken deferred signing on the 13th because it was a Friday. On the 13th Mackenzie King spent from 11:30 AM to 2:00 PM on the Manitoba agreement and from 3:00 to 7:00 PM on the Alberta agreement (King Diaries, ibid.).

King Diaries, ibid. (5 July 1928). 
constraints of the old BNA Act of $1867 . .^{99}$ Nevertheless, the Prime Minister was not always appreciative of what he called technicalities, and after the agreements had been signed, he noted that both Interior Minister Charles Stewart ${ }^{100}$ and Solicitor General Lucien Cannon ${ }^{101}$ had "complained a little of the speed at which we were proceeding but it would have been fatal to delay longer." 102 Stewart and Cannon may not have been unduly cautious; some aspects of the agreements and the very process were contested vehemently in the House of Commons, despite a general consensus for the need to transfer resources to the Prairie Provinces. $^{103}$

Although signed in mid-December, parliamentary action did not begin until late February 1930. ${ }^{104}$ Manitoba obtained assent for its legislation on 19 February $^{105}$ and Alberta on 3 April 1930. On 28 February 1930, Interior Minister Stewart gave notice of motion to the House of Commons: "That is expedient to bring a measure to confirm the agreement between the government of the Dominion and the province of Alberta, dated 14th December, 1929, respecting the transfer of the natural resources of Alberta." ${ }^{106} \mathrm{C} . \mathrm{H}$. Cahan (Conservative MP for St. Lawrence-St George) lead off the debate by questioning the school lands fund, but he quickly indicated disagreement with the process because the House had not seen the agreement before it had been executed, and because the provincial legislatures had adjourned before the House dealt with the agreements. He stated: "[t]he House of Commons is placed in the position that it cannot demand that the agreement be amended in certain essential particulars in order to carry out the clear intention of this house without taking the position of being entirely opposed to the transfer of these resources to the several provinces as intended"; he affirmed a good reason for his concern: "To understand the principles of this

Commonly referred to as the Constitution Act, 1867 (U.K.), 30 \& 31 Vict., c. 3, reprinted in R.S.C 1985, App. II, No. 5.

100

Charles Stewart, Liberal; Premier of Alberta and Minister of Railways and Telephone (18 October 1917 to 12 August 1921); Minister of the Interior, as cited in Greene, supra note 45 at 1640.

Lucien Cannon, K.C., LL.D. (Laval University); appointed Senior Crown Prosecutor for District of Quebec (1920); elected to Quebec Legislative Assembly in 1913 and re-elected 1916: elected to House of Commons 1917 and re-elected 1921, 1925, 1926; sworn in as Solicitor General (5 September 1925); re-appointed and sworn in as Privy Councilor (25 September 1926), as cited in A.L. Normandin, ed., The Canadian Parliamentary Guide: 1933 (Ottawa, Mortimer, 1933) at 31-32.

King Diaries, supra note 1 (14 December 1929).

See generally House of Commons Debates (1930) vols. 1 \& 2 (Ottawa: F.A. Acland, 1931).

See supra notes 4 and 6 . With respect to the enactment of the agreements in the House of Commons, the Manitoba and Alberta agreements were tabled on 26 I'ebruary 1930; the House went into committee to consider the resolutions on $4 \mathrm{March}$; the agreement with Saskatchewan was tabled on $28 \mathrm{March}$; printing of the correspondence between Saskatchewan and Alberta and the Dominion governments relating to the agreements was ordered on 31 March; a notice of motion to consider the resolution to confirm the Saskatchewan agreement was given on 31 March; debate occurred on second reading of the Manitoba agreement (originally introduced as Bill 18) and third reading on 28 April; second reading of Alberta agreement (introduced as Bill 17) began on 28 April and concluded with approval on 1 May: because of the similarity of the three agreements, the debate on the Saskatchewan agreement (introduced as Bill 58) was short and second reading and approval occurred immediately after the Alberta agreement on 1 May; address to the King confirming the agreements with message to the Senate from the House of Commons on 27 May 1930 (see House of Commons Debates (27 February 1930) at 148-49).

See supra note 4 (assented to 19 February 1930).

At the same time, the same notice was given in respect of the Manitoba agreement (House of Commons Debates (27 February 1930) at 149). 
statute one must look beneath the surface and consider the terms of the agreement itself." 107 Conservative leader R.B. Bennett expressed firmly his frustration with the process:

\begin{abstract}
May I say this? It is futile for us to make objections here. The Minister of Justice in the observations he made a few minutes ago indicated that we are but a rubber stamp. These agreements have been accepted by the respective legislatures and each constitutes now a contract between two parties, the province and the Dominion. We have no power to amend, we have no power to change, because no one party to a contract can change the contract without the consent of the other party. Therefore so far as this parliament is concerned we might as well accept these agreements and be done with them. All we can do is call attention to points which occur to us as we go along, and objections which we have to certain phases [phrases?] of the agreement; but as the minister very properly observed, it is too late to talk of changes once a contract is signed unless both parties thereto consent; and inasmuch as one party is not available for the purpose of making changes without long delay, there is nothing more to be said but to accept the agreements as they are. ${ }^{108}$
\end{abstract}

Bennett had serious objections to what he regarded as an unconstitutional process, stating emphatically, "once more I desire to repeat to this house that the Alberta agreement represents a contract invalid and illegal." 109 Additionally, the debate on the NRTAs also served to remind Members of Parliament of the constraints of the BNA Act and that they could only change the constitution by obtaining the approval of the Imperial Parliament.

To a large degree, the essence of the debate on these agreements was that critics pointed to the various restrictions placed on how the Prairie Provinces would administer their lands and resources after the transfer as a negation of the agreements' stated purpose of placing those provinces "in a position of equality with the other provinces of Confederation." ${ }^{10}$ The provision covering the school lands trust was the most contentious issue, arousing apprehensions about the federation responsibilities with respect to minority rights. "' Upon concluding his discussion of school fund issue, Cahan directed a final point at Lapointe: "the Minister of Justice must take the full responsibility with regard to the interpretation of that agreement" because this was a matter "of such peculiar importance to my own people in the

House of Commons Debates (28 April 1930) at 1528: for a summary of the debate, see J. Castell Hopkins, ed., Canadian Annual Review of Public Affairs: 1929-30 (Toronto: Canadian Review Company, 1930) at 50-53.

House of Commons Debates (28 February 1930) at 1542. He raised these objections again on 29 April 1930 (House of Commons Debates (29-30 April 1930) at 1579-80).

(11) House of Commons Debates (29 April 1930) at 1572. The Justice Department regarded Bennett's use of "illegal" not in the ordinary use of the word. but really to mean "extra legal." A memorandum concerning "Points Raised In Debate On Natural Resources" was prepared by the Justice Department on 6 May 1930 that reviewed the objections by Bennett and Cahan. This memorandum served as a draft of a 12 page analysis titled "Memorandum For The Honourable The Leader Of The Government In The Senate" (13 May 1930), reproduced in Ottawa, NAC, (RG 13, vol. 2420, file 532/1930). Preamble to the Manitoba agreement, supra note 4, scheduled with Bill 18.

III Some of the points raised in debate included: the ability to amend the agreement by both governments; the difference between the Alberta and Saskatchewan agreements with respect to the reference to the Supreme Court; school lands and school lands trust fund: the reference to s. 109 of the BNA Act. 1867 , supra note 99; the ability of provincial legislatures to effectively amend federal statutes relating to land issues; the lack of an explicit inclusion in the transfer agreement of one particular section of the Dominion Lands Act, S.C. 1879. c. 31 pertaining to school lands: the lack of assurance that royalty rates could not be changed by the provinces during the life of an existing lease: water power: Dominion ownership of national parks and its exclusive jurisdiction; the amount of subsidies paid to the provinces; and the ability to change the agreement by concurrent provincial and federal legislation. 
province of Quebec." ${ }^{12}$ After some general debate during the second reading of Bill $18,{ }^{113}$ approval was given on a paragraph-by-paragraph basis. Significantly, during the examination of Bill 18, paras. 9 to 14 inclusive (water power, fisheries, Indian reserves, Indian livelihood rights, and solider settlements lands) were all agreed to without comment or debate. ${ }^{114}$ The Debates of the House of Commons provide a fascinating account of the efforts to undue the decision to retain the lands and resources of the Northwest and Manitoba for the "purpose of the Dominion"; however, this source does not provide any specific insight about the nature and origin of the Indian livelihood right. A better understanding of the Indian livelihood right provision can best be attained by reconstructing the drafting of the provision.

After Canadian approval, the agreements were forwarded to the Imperial Parliament. The Secretary of State for Dominion Affairs in London advised the Secretary of State for External Affairs on 25 June 1930 that the Bill confirming the agreements had been introduced in Imperial Parliament, which passed in time to ready Manitoba's compensation cheque $(\$ 4,584,212.49) .{ }^{115}$ Mackenzie King and Lapointe participated in Manitoba's Diamond Jubilee celebration of Manitoba's entrance into Confederation and the presentation of the cheque laid to rest an old grievance. ${ }^{116}$

After the understanding of April 1922, it took some eight years marked by throne speech promises, Dominion/Provincial conferences, negotiations, a failed agreement, fears about sectarian disputes over school funding, and Orders in Council, before concurrent provincial, federal and imperial legislation resolved what had been a 60 year problem for Manitoba. Clearly, negotiating the transfer of resources was not a haphazard process. The process leading to general terms of reference that was acceptable to Manitoba and Dominion politicians resolved the old problem of compensation; nonetheless, the existing trusts and obligations were a vital responsibility for federal officials, and therefore, observant drafting of specific terms had to be completed before an agreement would be executed. Dominion records provide the most important evidence concerning the drafting of the terms of the agreement that recognized a variety of trusts and obligations. The 1926 Alberta agreement served as a template for the 1929 talks. In this sense, the 1926 Alberta and 1929 Manitoba agreements are strongly linked and to appreciate the complexity of the Indian livelihood rights provision, it is necessary to back-track to examine the development of the 1926 agreement with Alberta.

\section{The Treaty Hunting and Fishing Right IN THE 1926 ALbERTA AGREEMENT}

If the historical importance of the 1930 NRTA has not received adequate scholarly attention, then the stillborn 1926 Alberta-Canada agreement is an even more obscure

House of Commons Debates (28 April 1930) at 1536

Introducing the Manitoba agreement, supra note 4 into Parliament. See also supra note 104

House of Commons Debates (1930) at 1541; also, the debate on the Alberta and Saskatchewan agreements did not generate any discussion of para. 12 (House of Commons Debates (I May 1930) at 1702-704).

15. The details concerning the approach to the Imperial Parliament with the Bill to confirm the amendment of the BNA Act, supra note 6 can be found in Ottawa, NAC (RG 25, vol. 797, file 507); and Ottawa, NAC (RG 13, vol. 2420, file 532/1930).

King Diaries, supra note 1 (15 July 1930). 
development but which requires analysis. Charles Stewart, former premier of Alberta, as Interior Minister was in charge of the legislation introduced in March 1926. On the Dominion side, the Department of the Interior took the leading role during the 1925-26 negotiations. A central figure in the 1925-26 negotiations was Lieutenant-Colonel O.M. Biggar K.C., Chief Electoral Officer and counsel for the Dominion. ${ }^{117}$ While the position of the Dominion government with respect to Indian interests in the transfer went through subtle developments in the 1925-26 period, this detail is an essential starting point for an understanding of the agreement achieved on 9 January 1926.

The Department of Indian Affairs was alert to the real possibility of a transfer of resources as early as 1922 , but not until January 1925 did it seem that the agreement with Alberta was imminent. ${ }^{118}$ In 1925, the main concerns were the administration and beneficial interest of Indians in reserve lands and outstanding reserve lands, including the land needs of non-treaty bands. ${ }^{119}$ In January 1925, Duncan Campbell Scott, ${ }^{120}$ Deputy Superintendent General of Indian Affairs, formally outlined the main Indian interest issues. Scott identified the obligation for outstanding reserves and the need to secure for Indians reversionary beneficial interests in reserve lands. Under the heading of "Hunting and Fishing," he noted: "[w]hile the Indians shall be subject to the game laws of the Province, provision should be made for hunting and fishing reserves, and for exemptions in favour of Indians who are hunting and fishing purely for their own sustenance." 21 Scott had proposed hunting reserves for Indians. In the Northwest Territories the Dominion government created vast "game reserves" in which lands were specifically set aside to allow Aboriginal people to secure traditional livelihoods. $^{122}$

Biggar, through consultation with Scott, drafted a memorandum on 30 January that listed the Indian interests: reserves surveyed and confirmed, reserves surveyed but unconfirmed,

117 Oliver Mowatt Biggar, C.M.G., K.C., B.A. (Osgoode Hall); practiced with Biggar and Burton (19011902); Short, Cross and Biggar (1903-1915); Woods, Sherry, Collison and Field (1915-1920); Smart and Biggar (1927-); Judge Advocate General for Canada (1918-1920); and Chief Electoral Officer (1920-1927) as cited in B.M. Green, ed., Who's Who in Canada: 1947-48, vol. 36 (Toronto: International Press, 1948) at 384.

118 The Indian Affairs file on the transfer agreement opened on 6 March 1922 and the material relating to the 1926 agreement begins on 19 January 1925 (Ottawa. NAC (RG 10, vol. 6820, file 492-4-2, pt. 1)). The file material from the Hudson's Bay Company concerning the transfer of resources begins on 24 December 1924.

11.) Memorandum, Robertson, Ottawa, NAC, public records of the Department of Indian Affairs (RG 10, vol. 6820, file 492-4-2, pt. 1). As background to the negotiations, Chief Surveyor Donald Robertson recorded the needs of the Yellow Face Band for 16 square miles of reserve lands. This indicates a recognition that Non-Treaty Indians had a stake in the transfer.

120 For a biography of Scott, see E. Brian Titley, A Narrow Vision: Duncan Campbell Scott and the Administration of Indian Affairs (Vancouver: University of British Columbia Press, 1986) at 23-24. where Titley described Scott as a "government mandarin" who had begun as a copy clerk in 1879 . served as bookkeeper, was prompted to clerk in charge of accounting branch, rose to chief clerk and accountant, was appointed to Treaty 9 commissioner in 1905, served as superintendent of education. and then, from 1913 to 1932, directed the department as deputy superintendent general.

121 "Memorandum, so far as the Indian interest is concerned, regarding the proposed transfer from the Dominion to the Province of Alberta of the administration of the natural resources of the Province" (29 January 1925), Ottawa, NAC (RG 10, vol. 6820, file 492-4-2, pt. 1). Scott raised the hunting issue without reference to treaties.

122 For example, the Thelon Game Sanctuary was established in June 1927. 
and additional reserves pursuant to treaties. ${ }^{123}$ Biggar believed that it was not necessary to raise the reversionary interest to surrender lands, since Indian reserves were to remain as Dominion lands after the transfer. He also provided regional background on the traditional economy: "The situation in regard to game is difficult"; and "[i]n southern Alberta the Indians have become agriculturists and have ceased to depend for their livelihood on hunting, but this is by no means the case in the north, where many of the bands depend upon trapping and fishing for a livelihood." 124 The problem of Indian hunting and game conservation was explained:

The Department of Indian Affairs is just as much, or even more concerned to secure the preservation of game than the provincial authorities themselves. In the old days the Indians themselves took care to conserve and protect the game so as to yield them their livelihood as readily as possible, and they were in effect the only trappers. Now, however, the commercial trappers show no such concern, and, for example, when they take beaver, destroy the beaver house and take the pups. This sort of thing, though against the law, is impossible effectively to prevent and the result is the gradual disappearance of the game and probably some alteration in the attitude of the Indians themselves, who, finding their own efforts to conserve the game fruitless, are inclined to be less careful.

The diminution in the quantity of game presses hardly upon the hunting Indians, and it is not without importance that, notwithstanding the game laws, they should be allowed to hunt and fish out of season for their own food. ${ }^{125}$

From the point of view of Dominion officials, the reckless encroachment by White trappers on traditional Indian lands was the cause of conservation problems. The example of the beaver was used to illustrate "the disappearance of the game." Biggar drew a distinction between the traditional behaviour of Indians as trappers and the practices of commercial trappers. His usage of the term "commercial" in the first instance was linked with overexploitation. Since the point of trapping of beaver by Indians was for cash-valued exchange, his usage of commercial has to be considered qualified. Biggar identified a potential problem with respect to Indian access to what would become provincial Crown lands and conceded that "[i]t would nevertheless be advisable to include in the arrangement with Alberta a provision definitely making the Indian treaty provisions apply." 126 The view was expressed that livelihood rights were more important in the northern areas and that provincial laws might apply because of differences in the wording of the various Alberta treaties. However, Biggar argued that the application of provincial game laws to Indians was an issue that need not be raised at this point. ${ }^{127}$

Throughout the process for reaching an agreement on transferring resources, Scott and Biggar differed on how and which Indian interests to protect. Biggar provided legal

Memorandum, Biggar (30 January 1925), Ottawa, NAC (RG 10, vol. 6820, file 492-4-2, pt. 1).

Ibid.

Ibid. Biggar's use of the example of beaver indicates that the expression hunting included trapping. The reference to Indians as trappers also exhibits an awareness of the traditional economy.

Hunting, trapping, and fishing in Treaty 8 were "subject to such regulations as may from time to time be made by the Government of the country" (see Canada, Treaty No. 8 made June 21, 1899 and Adhesions, Reports (Ottawa: Queen's Printer, 1966)).

Ottawa, NAC (RG 10, vol. 6820, file 492-4-2, pt. 1). 
perspectives for restricting the scope of the issues to be included in the agreement. In response to Biggar's cautious approach to Indian interests, Scott consulted with the Indian Affairs solicitor A.S. Williams. In a memorandum of 6 February 1925, Williams disagreed with Biggar's strategy and he provided several reasons for supporting Scott's position.

It seems to me that these matters should be dealt with in the proposed legislation and not left to be worked out in the future with the Province of Alberta or to be determined by the courts of law. The Dominion is in a better position now than it will ever be hereafter to assert what it conceives to be the rights and interests of the Indians and to secure consideration of these interests from the Provincial Authorities. ${ }^{128}$

In this memorandum, Williams also raised the general problem of jurisdiction over treaty hunting and fishing by citing the livelihood rights of the Robinson Superior Treaty. For several decades, the Department of Indian Affairs had been involved in serious jurisdictional disputes with the Province of Ontario concerning the regulation of Indian hunting in the Robinson Treaty territories. The specific written terms of the Robinson Treaties had little direct bearing on Alberta Indians, however, the jurisdiction dispute was not a matter that any official cognizant of Indian interests would want to leave to the future discretionary actions of provincial authorities.

In this context, Williams quoted a Justice Department opinion of 5 October 1917 that advocated immunity from provincial game laws for Indians based on the paramount Dominion powers with regard to Indians and lands reserved for the Indians; Williams concluded " that it would be quite regular and advisable that the provision should be inserted in the proposed act providing for special privileges of hunting and fishing for the Indians located in that part of the Province where they have to depend for their livelihood upon hunting and fishing." 129 The reference to the Robinson Treaty and the Justice Department opinion of 5 October 1917 could only serve to remind Scott of the difficulties created by two decades of Ontario's aggressive encroachment on Indian livelihood. ${ }^{130}$ Scott concurred with Williams' memorandum. ${ }^{131}$ Williams' memorandum confirms that civil servants were mindful of the need to protect Indian interests as part of the process of transferring natural resources.

Understandably, Colonel Biggar was not fully aware of the implications of Williams' reference to conflicts relating to the Robinson Superior Treaty and to the Justice Department Opinion of 5 October 1917 or of the problems that Ontario Indians were having in exercising treaty livelihood rights. He requested copies of the Alberta treaties and pointed out that hunting rights should not change, but "should be limited to continuing to the Indians the same

Memorandum, Williams to Scott (6 February 1925), Ottawa, NAC (RG 10, vol. 6820, file 492-4-2, pt. 1).

12.) Ibid. [emphasis added].

131 Frank Tough, "Ontario's Appropriation of Indian Hunting: Provincial Conservation Policies vs. Aboriginal and Treaty Rights, Ca. 1892-1930" (Toronto: Ontario Native Affairs Secretariat, 1991). This source and the argument of this piece of primary research was acknowledged in Canada. Royal Commission on Aboriginal Peoples, Report of the Royal Commission on Aboriginal Peoples: Restructuring the Relationship, vol. 2 (Ottawa: Minister of Supply and Services Canada, 1996) at 49698.

131 Memorandum, Scott to Biggar (9 February 1925), Ottawa, NAC (RG 10, vol. 6820, file 492-4-2, pt. 1). 
rights in unoccupied Crown lands after their transfer to the Province as they now enjoy in respect of them."132 In other words, the rights should be preserved.

Later, Biggar provided for Scott's consideration a draft of his memorandum to the Prime Minister. Under the heading "Appendix H" entitled "Indian Lands," the Indian interests are explained. With respect to livelihood rights, Biggar reported that "the Department of Indian Affairs would like to have included in the agreement express provisions ... (c) guaranteeing to the Indians the right to hunt and fish on unoccupied Crown lands, and (d) relieving the Indians wholly or partly from the obligation to comply with the provincial game laws." 33 Biggar understood the need to protect access to unoccupied Crown lands, but he remained unconvinced about any potential conflict between provincial laws and Indian rights:

The fourth point [d] has no relation to lands, but to legislative jurisdiction over Indians as such, and since this is assigned by the British North America Act exclusively to the Dominion, I think that it is unnecessary and would be dangerous to make any reference to the subject in an agreement with the Province of Alberta which must be confirmed by concurrent statutes; the only possible effect of a provision on this point would be to narrow unnecessarily the Dominion's present plenary power. ${ }^{134}$

At this point in the negotiations, the issue of Indian livelihood after the transfer centred on access to unoccupied Crown lands and the application of provincial game laws to Indians. These problems were not unrelated to the Dominion government's obligation to uphold treaties. However, the paramount powers of the Dominion government with respect to Indians had not been of pragmatic benefit to Indians when the Province of Ontario argued that provincial game laws could alter treaty rights. Despite Dominion jurisdiction in respect of Indians, the administration of lands and natural resources was held by the provinces; thus, access to lands and game regulations was based on provincial jurisdiction. With respect to ensuring the livelihood rights of Indians, Scott was acting pre-emptively to limit what would become provincial authority in respect of game regulations. His suggestion that hunting and fishing reserves be set aside was not taken up.

By early June 1925, a draft of the terms relating to Indian interest was ready. Charles Stewart, Minister of the Interior, agreed to the terms on Indian reserves and Indian hunting (paras. 8 and 10), but he had the term on reversionary interest removed (para. 9). ${ }^{135}$ The livelihood term stated:

10 [9]. To all Indians who may be entitled to the benefit of any treaty between the Crown and any band or bands of Indians, whereby such Indians surrendered to the Crown any lands now included within the boundaries of the Province, the Province hereby assures the right to hunt and fish on all the unoccupied Crown lands administered by the Province hereunder as fully and freely as such Indians might have been permitted to so hunt and fish if the said lands had continued to be administered by the Government of Canada. ${ }^{136}$

132 Memorandum, Biggar to Scott (12 February 1925), Ottawa, NAC (RG 10, ibid.).

1.3. Draft Memorandum, Biggar to Scott (17 February 1925), Ottawa, NAC (RG 10, ibid.).

134 Ibid.

135 Draft agreement attached to Memorandum, Scott to Stewart (4 June 1925), Ottawa, NAC (RG 10, ibid.)

1.3. Ibid. [emphasis added]. Scott continued to press for inclusion of an Indian beneficial interest in reserve surrenders. A draft of this term existed in early 1925 (see Memorandum, Scott to Bigger (20 February 1925), Ottawa, NAC (RG 10, ibid.)). 
This 1925 draft of the wording for para. 10 is identical to the wording of para. 9 in the final 1926 agreement. Thus, the negotiations with Alberta officials did not affect the Dominion's position on the Treaty Indian interest in livelihood.

Basic agreement was reached between the federal and provincial governments in the summer of 1925. ${ }^{137}$ An agreement for the transfer of lands was signed by the Dominion of Canada and the Province of Alberta on 9 January 1926. A copy of this agreement was scheduled with a House of Commons unnumbered Bill entitled An Act respecting the Public Lands in the Province of Alberta. The agreement of 9 January with Alberta was tabled in the House of Commons by Interior Minister Stewart on 26 January 1926. ${ }^{138}$ The House of Commons Bill was prepared for a first reading in March 1926. ${ }^{139}$ The Alberta legislature's first reading of Bill 32 "An Act respecting the Transfer to the Province of the Public Lands therein" occurred on 24 February 1926 and this Bill passed and was assented to on 22 May $1926 .{ }^{140}$

Changes made to the school lands paragraph in s. 2(a) of the Alberta legislation materially altered one effect of the 9 January 1926 agreement. ${ }^{141}$ This issue confounded the political and legal process attempting to transfer resources. ${ }^{142}$ In the House of Commons, the Bill simply

137 On 28 July 1925, Charles Stewart indicated to the HBC that no agreement had been reached. A copy of the draft agreement was submitted to the Alberta legislature in August 1925 and the HBC had a copy of the agreement on 6 August 1925 (Winnipeg, AM, Hudson's Bay Company Archives [HBCA] (RG 2/7/431, Canadian Committee Office Records)). However, on 4 July 1925 Biggar informed the Minister of Marine and Fisheries. P.J.A. Cardin, that an agreement "has been settled as a result of the conferences which have been had with the Premier and the Attorney General of the Province" (Memorandum, Biggar to Cardin (4 July 1925), Ottawa, NAC, public records of the Department of Marine and Fisheries (RG 23, vol. 1049, file 721-8-7, pt. 1)). However, the fundamentals were probably settled earlier. Mackenzie King wrote: "On Tuesday Greenfield [Premier of Alberta] brought me a letter accepting transfer of Natural Resources to Alberta on the terms we laid down \& which I have refused under pressure to lessen - another good piece of work" (King Diaries, supra note 1 (18 December 1924)).

1:3 House of Commons Debates (26 January 1926) at 428-29.

13) A typeset copy of the proposed bill can be found in Winnipeg, AM (RG 17, Al, file 14). On 18 March 1926. Prime Minister W. L. Mackenzie King moved that House go into committee to consider a resolution on the transfer of resources to Alberta (House of Commons Debates (18 March 1926) at 1665).

140 Bill 32, An Act respecting the Transfer to the Province of the Public Lands therein, 6th Sess., 15 th Leg. Alberta, 1926; a copy can be found in Winnipeg, AM, HBCA (RG 2/7/430). Second reading occurred on 5 March and third reading 22 May 1926; the statute was designated An Act respecting the Transfer to the Province of the Public Lands therein, S.A., 1926, c. 69.

$1+1$ The Alberta legislature changed the reference to the use of the school lands funds from the terms set out in s. 17 of the Alberta Act. 1905, supra note 62 to "the laws of the Province" in the NRTA. supra note 6. Ernest LaPointe. Minister of Justice, explained this development in the House of Commons (sec House of Commons Debates (1926) at 3922-23 and 3976-77). For details of the school lands issue, see also J. Castell Hopkins. ed., Canadian Anmual Review of Public Affairs: 1925-26 (Toronto: Canadian Review Company, 1926) at 494-96.

142 Prime Minister Mackenzie King explained the School lands question: "Council [Cabinet] at noon, took up the Alberta Resources question - Lapointe I fear may draw us into a school question. ... The whole trouble is due to Lapointe's fear of Bourassa [Henri Bourassa. Independent MP for Labelle], and allowing an unnecessary section to be added to the bill drafted for Prov'l and Fed'l acceptance"(King Diaries, (25 May 1926)). The next day, after a caucus meeting he recorded: “...there was quite a vigorous discussion, which disclosed how easily the whole matter might become one of bitter controversy - and the necessity for preventing anything of the kind at any cost." Alter the caucus meeting several cabinet ministers met with Mackenzie King and decided to have the school lands issue 
remained on the order paper and the substance of the Bill was not debated. ${ }^{143}$ The inability to enact the Alberta agreement and to transfer the resources as promised in the Throne Speech was one of many factors that resulted in the fall of the Mackenzie King Liberal government in June 1926. ${ }^{144}$ Nonetheless, in terms of legal and political negotiations, the 1926 agreement was not an unfinished draft. And although long forgotten, both governments acted on the basis of the agreement. Indian interests were not impinged upon by the potentially acrimonious problem of the school lands trust fund. Therefore, the 1926 Alberta Agreement is a significant document embodying the specific intentions involved with the transfer of natural resources to Alberta at a particular point in the process.

With respect to Indian hunting, para. 9 of this 9 January 1926 agreement stated:

9. To all Indians who may be entitled to the benefit of any treaty between the Crown and any band or bands of Indians, whereby such Indians surrendered to the Crown any lands now included within the boundaries of the Province, the Province hereby assures the right to hunt and fish on all the unoccupied Crown lands administered by the Province hereunder as fully and freely as such Indians might have been permitted to so hunt and fish if the said lands had continued to be administered by the Government of Canada. ${ }^{145}$

The Treaty Indian livelihood rights provision was not altered in the 1925-26 negotiations between Alberta and the Dominion, as it is identical to the draft agreed to by Charles Stewart in June 1925 (see Appendix A). Because HBC interests were involved in the transfer, its solicitor David H. Laird actively monitored the negotiations and lobbied for the Company. ${ }^{146}$ Not surprisingly, the HBC welcomed the two clauses ( 8 and 9) on Indian interests, as Laird noted: "These are important as indicating that the Province is bound to permit the Indians to

referred to Court (King Diaries, supra note 1 (26 May 1926)). A reference by Order-in-Council of 24 June 1926 (P.C. 1023) to the issue of Alberta school lands (s. 17 of the Alberta Act, ibid.) went to the Supreme Court of Canada and was heard on 7 March 1927; and a judgment was given on 20 April 1927 that s. 17 was not ultra vires the Parliament of Canada (see supra note 63; see also Ottawa, NAC (RG 13, vol. 2520, file C-1008)).

143 This was a matter of complaint. When the House was in committee to consider the Alberta agreement, MP (Toronto Northwest) Thomas Langton Church K.C. (Conservative) stated: " $t$ ] he government of the day kept that resolution on the order paper for four or five months so that no one could ask any questions about it until the minister reintroduced it"(House of Commons Debates (4 March 1930) at 246).

144 See House of Commons Debates (14, 15, and 30 June 1926) at 4432, 4493-95, 5195, and 5206. In an effort to save his minority government, several issues proved problematic for the Prime Minister. The importance of the Alberta Natural Resources question, including consideration of transferring Alberta resource without school lands, is evident in his personal diaries (see King Diaries, supra note I (15 to 22 June 1926)).

145 Agreement Made On The Ninth Day Of January, 1926 Between The Dominion Of Canada And The Province Of Alberta: On the Subject of the Transfer To The Province Of Its Natural Resources (Ottawa: F.A. Acland, 1926). Typeset copy found in Winnipeg, AM (RG 17, Al, file 14) [emphasis added] [1926 Alberta agreement].

146. David Henry Laird, K.C., M.A. and LL.D. (Queen's University); articled in Manitoba with Munson and Allan (1899); admitted to the Manitoba Bar (1902); practiced with Munson, Allan. Laird and Davis. later Laird, MacInnes and Co.; his standing in the community was later recognized with his service as Vice-President of the Canadian Bar Association - Manitoba (1933-34) and as President of the Law Society of Manitoba (1939-41) (Winnipeg, AM, David H. Laird, P1276). 
hunt and fish on the Crown lands." ${ }^{47}$ For both the HBC and Indians, traditional access to Crown lands for livelihood purposes was vital. Otherwise, it would be difficult for the HBC to continue its commercial fur trade operations. The HBC was not impressed by what it regarded as undue regulation of the traditional economy. ${ }^{148}$

Essentially, para. 9 in the 1926 agreement ensured access to unoccupied Crown lands and indicated that Treaty Indian hunting and fishing would continue as before the transfer. In this sense, there was no separation of the commercial and subsistence aspects of the mode of life. Without making direct reference to provincial game laws or risking the danger of narrowing Dominion jurisdiction, para. 9 simply provided for the continuation of Indian hunting and fishing. A full and free right to hunt and fish on unoccupied Crown lands on the same basis as if under the Dominion administration would be consistent with the pre-1926 situation and would comport with a narrow view of the written treaties. The lack of directness on the question of provincial game laws may have satisfied Biggar's concern about the danger of unnecessarily narrowing Dominion powers. ${ }^{149}$ The expression "any treaty" served to standardize the regulatory authority concerning Indian avocations and vocations of hunting and fishing, thereby clarifying the different wording used in the various Alberta treaties. Although inelegant, the references to treaties with the Crown, land surrenders to the Crown, and bands are all expressions pertinent to the definition of a Treaty Indian. In this respect, the 1926 Alberta agreement intended to secure treaty livelihood rights.

\section{THE INDIAN LIVELIHOOD RIGHT IN the 1929 Manitoba Agreement}

The failure to complete the 1926 agreement had implications for the manner in which the 1928-1929 process for transferring resources was conducted. With the collapse of the 1926 agreement, the focus of activity concerned the work of the Royal Commission on the Transfer of the Natural Resources of Manitoba headed by W.F.A. Turgeon. Notably, the Province of Manitoba took a lead in setting an agreement for the Prairie Provinces. Following the report of the Manitoba Natural Resources Commission (May 1929) (150 $^{15}$ and the concomitant political resolution of the financial compensation issue, Manitoba was ready to negotiate the other terms of an agreement. Manitoba and Dominion negotiators met at the end of August 1929. ${ }^{151}$ The records of both the Department of Indian Affairs and the Hudson's Bay Company indicate that the issues that lead to the final agreement were initially discussed between

147 See Memorandum, Laird to W.S. Lecky, Secretary, Canadian Committee (1 September 1925), Winnipeg, AM, HBCA (RG 2/7/428), in which Laird provided a four page analysis of the agreement. These $\mathrm{HBC}$ records provide useful additional details and another perspective on the transfer process. See e.g. Confidential Memorandum for the Minister of the Interior re: see Game Law 1892-1916, C.C. Chipman (HBC Commissioner) (17 April 1894), Winnipeg, AM, HBCA (A 12/FT 230/1). of government had jurisdiction over Indian hunting on provincial Crown lands.

(5) See Manitoba Report, supra note 71

151 Memorandum of an Interview which the Honourable D.G. McKenzie and Mr. R.W. Craig. K.C.. representing the Province of Manitoba and had with the Minister of the Interior, Honourable Chas. Stewart and the Acting Deputy Minister, Mr. Roy A. Gibson (27 August 1929) Winnipeg, AM (RG 17. Al, file 1). 
Manitoba and Canada. ${ }^{152}$ In particular, David H. Laird, a well-connected legal advisor and lobbyist for the $\mathrm{HBC}$, provided an interesting set of non-governmental records on the events associated with effecting the transfer. ${ }^{153}$

Not surprisingly, the Justice Department acquired a stronger role in creating the agreement. For a start, the Justice Department was involved with the Alberta school lands and s. 17 of the Alberta Act, $1905^{154}$ in the Supreme Court. Apparently, reaching an agreement with Manitoba was not left simply as the responsibility of Biggar and the Interior Department. At a major conference on 26 June 1929 between Mackenzie King and senior cabinet ministers and Bracken, his cabinet ministers and solicitors, in which the recommendations of the Manitoba Resources Commission were accepted, King recorded that "...it was agreed that sol'rs [solicitors] of the Justice Dept. should prepare the necessary legis'n [legislation] \& agreement of transfer, Mr. Stewart's Dept. [Interior] cooperating." 155 Thus, the Justice Department had major responsibilities with the conclusion of the Manitoba Resources Commission. When Colonel Biggar was re-engaged for the preparations for the transfer agreements, he informed Duncan Campbell Scott that he was acting for the Justice Department. ${ }^{156}$ The involvement of the Manitoba Natural Resources Commission (1928-29) in the transfer of resources was a modification of the 1924-1926 process with Alberta. As a result, the responsibilities of the Justice Department are more evident.

After the collapse of the Alberta agreement and with the establishment of the Manitoba Resources Commission, the Indian interests were reviewed; these interests and trusts were reconsidered. This was a new opportunity for Scott to pursue issues that had not been accepted by Colonel Biggar and Charles Stewart back in 1925 and 1926. The Department of Indian Affairs file concerning the transfer was re-activated by a request from the Deputy Minister of Justice W. Stuart Edwards. ${ }^{157}$ In November 1928, Edwards notified Scott of the responsibilities of the Manitoba Natural Resources Commission and stated: "[i]n the meantime, this Department is required to instruct and brief counsel to present the Dominion's

152 Ibid.; and see e.g. Memorandum, Chisholm to Scott (28 August 1929), Ottawa, NAC (RG 10, vol. 6820, file 492-4-2, pt. 1); and Memorandum, Scott to Chisholm (4 September 1929), Ottawa, NAC (RG 10 , ibid.). In the 1925-1926 negotiations, HBC solicitor David H. Laird lobbied the Premier of Alberta, but in the 1929 negotiations Laird held his meetings with counsel and senior politicians from Manitoba (Memorandum, David H. Laird on the 14 December 1929 agreement (16 December 1929) Winnipeg, AM, HBCA (RG 2/7/437) [Laird Memorandum]). Also indicative of Manitoba's lead role is Deputy Minister of Justice W. Stewart Edwards' telegram informing R.W. Craig that "Interior Department advises that draft agreement is being speeded up as much as possible and that you will be advised so soon as first draft has been completed" (Telegram, Edwards to Craig (25 September 1929), Winnipeg, AM (RG 17, A1, file 1)).

See e.g. Laird Memorandum, ibid.

See supra note 62.

King Diaries, supra note 1 (26 June 1929).

Memorandum, Scott to Biggar (22 October 1929), Ottawa, NAC (RG 10, vol. 6820, file 492-4-2, pt 1).

W. Stuart Edwards, K.C.; studied law with the firm O'Gara, Wyld and Osler (Ottawa); called to the Bar (1909); practiced with McCarthy, Osler, Hoskin and Harcourt (Toronto); appointed legal staff Department of Justice (1910); appointed Department Secretary (1913); appointed Assistant Deputy Minister of Justice (1915); appointed Deputy Minister of Justice (1924); appointed Dominion K.C. (7 January 1927); and K.C. Ontario (31 May 1928), as cited in Normandin, supra note 22 at 654. 
contention before the Commission upon the subject of the inquiry."158 The Justice Department was also charged with the responsibility of preparing the agreement and legislation. ${ }^{159}$ Minister of Justice Ernest Lapointe was involved in the process and was particularly concerned about the transfer of trusts and the politics of the school lands. ${ }^{160}$

The Justice Department began its own careful assessment of Crown and non-Crown interests involved with the transfer. ${ }^{161}$ Acting Deputy Minister of Justice J. Chisholm indicated that provisions similar to clause 8 and 9 of the 1926 Alberta agreement were proposed at the opening of the 1929 negotiations, however, Manitoba had requested specific information on outstanding reserve lands and had indicated that " $\mathrm{t}]$ he Province of Manitoba also desires to know what privileges of hunting and fishing the Indians within the Province are now entitled to under Dominion laws." 162 At this point, Chisholm had also suggested the inclusion of language similar to the Aboriginal rights sections of the 1912 statutes that extended the Ontario and Quebec boundaries. ${ }^{163}$ Thus, the Department of Justice was alert to the possibility of Indian interests in unceded territories. The Justice Department's request for information had the effect of allowing Scott to restate his priorities, some of which had not made it into the 1926 Alberta agreement.

Duncan Campbell Scott provided a detailed response for the Justice Department in a crucial document of 4 September $1929 .{ }^{164} \mathrm{He}$ began by suggesting that the provisions of the 1926 Alberta agreement were relevant:

Memorandum, Edwards to Scott (6 November 1928), Ottawa, NAC (RG 10, vol. 6820, file 492-4-2. pt. 1). Edwards requested information from the Department of Indian Affairs to assist the Dominion's case before the Commission.

Chisholm informed Scott that the Justice Department "has been instructed to prepare the agreement and legislation which will be necessary to implement the terms of the Order-in-Council of l st August. 1928. (P.C. 2158, supra note 83), and the recommendations embodied in the report of the Royal Commission touching the transfer of the natural resources of Manitoba to the Provincial Government" and he asked for matters that should be included in the agreement (sec Memorandum, Chisholm to Scott (2 August 1929), Ottawa, NAC (RG 10, vol. 6820, file 492-4-2, pt. 1)).

For examples, see King Diaries, supra note 1 (21 May 1926; 21 and 22 June 1926; and 6 July 1928).

Assistant Deputy Minister of Justice J. Chisholm requested: "please be good enough to enumerate fully any trusts existing in respect of the unalienated Crown lands within Manitoba and also any interests other than those of the Crown in the same, of which your Department has knowledge"(Memorandum. Chisholm to Scott (28 August 1929), Ottawa, NAC (R(i 10, vol. 6820, file 492-4-2, pt. 1)). Ibid.

1..3 Ontario Boundaries Extension Act, S.C. 1912, c. 40 s. 2 (a), (b), and (c); and Quebec Boundaries Extension Act, S.C. 1912, c. 45, s. 2 (c), (d), and (e). With regard to the northward extension of Quebec boundaries, s. 2(c) provided: " $[t]$ hat the province of Quebec will recognize the rights of the Indian inhabitants in the territory above described to the same extent, and will obtain surrenders of such rights in the same manner, as the Government of Canada has heretofore recognized such rights and has obtained surrender thereof, and the said province shall bear and satisfy all charges and expenditure in connection with or arising out of such surrenders." Scott felt that the inclusion of this sort of provision was unnecessary because Aboriginal title in Manitoba, unlike northern Ontario and Quebec had been surrendered by treaty.

1..4 Memorandum, Scott to Acting Deputy Minister of Justice J. Chisholm (4 September 1929). Ottawa. NAC (RG 10, vol. 6820, file 492-4-2, pt. 1) [Scott Memorandum]. 
In reply I beg to say that Clauses 8 and 9, as contained in the Alberta Agreement, would be quite satisfactory and sufficient to preserve the rights and privileges now enjoyed by the Indians of the Province in respect of their Reserves and their hunting rights and the proper administration of their affairs. ${ }^{165}$

Here, Scott did not distinguish between Treaty Indians and other Indians, but he noted that these terms preserved the existing arrangements. Given that the focus of the negotiations had shifted to Manitoba, he explained the livelihood rights of the Manitoba treaties:

Manitoba is covered by what are known as Treaties Nos. 1, 2, 3, 4 and 5 . The first two contain no provision with respect to hunting and fishing. Treaties 3,4 and 5 contain provisions stipulating that the Indians who are parties to these treaties shall continue to enjoy their rights of hunting and fishing throughout the tracts surrendered subject to such regulations as may from time to time be made by the Government of the Dominion of Canada, saving and excepting such tracts as may be required from time to time for settlement, mining or other purposes by the said Government. ${ }^{166}$

Significantly, Scott provided an interpretation of Treaties 1 and 2 based strictly on the written version of the treaty. ${ }^{167} \mathrm{He}$ also explained how existing federal legislation, unless declared otherwise through public notice, exempted Indians from the application of provincial game laws.

Policies, and not just treaties and legislation, were also an important aspect of Indian hunting in this era:

I may state that while the Department, as a matter of policy, has not opposed a reasonable enforcement of the Game Laws so far as the Indians are concerned, I am inclined to think that in the absence of Public Notice given under the provisions of said Section 69 of the Indian Act [providing the application of provincial game laws] the Game Laws of the Province could not prevail against the provisions of the Treaties above referred to. $^{168}$

In an indirect manner, Federal legislation lent qualified and discretionary support to Indian hunting rights, but as a matter of policy, the Indian Affairs Department admitted that it had not opposed the application of provincial game laws. The Department did not act to uphold treaty rights if the application of provincial games laws seemed reasonable. Thus any Dominion sense of obligation to Indians was not absolute and mostly likely differed from Treaty Indian understandings of their treaty-based livelihood rights. Possibly, exemptions

Ibid. Scott's correspondence was addressed to the Deputy Minister of Justice, in fact Chisholm was Acting Deputy Minister of Justice.

Ibid. [emphasis added].

Despite the absence of written hunting and fishing rights in Treaties 1 and 2, other written documents indicate that the Crown promised the right to hunt (see Frank Tough, "As Their Natural Resources Fail": Native Peoples and the Economic History of Northern Manitoba, 1870-1930 (Vancouver: University of British Columbia Press, 1996) at 92-93).

Scott Memorandum, supra note 164. Section 69 of the Indian Act, R.S.C. 1927, c. 98 provided: "[t]he Superintendent General may, from time to time, by public notice, declare that, on and after a day therein named, the laws respecting game in force in the province of Manitoba, Saskatchewan or Alberta, or the Territories, or respecting such game as is specified in such notice, shall apply to Indians within the said province or Territories, as the case may be, or to Indians in such parts thereof as to him seem expedient." In his memo, Scott referred to an 1895 view by the Minister of Justice which challenged the validity of several provisions of Manitoba game legislation. 
from provincial game laws for Treaty 1 and 2 Indians were based on s. 69 of the Indian Act. ${ }^{169}$ Scott did not distinguish between treaty rights and rights protected by s. 69 of the Indian Act. At this point, Manitoba's query had the effect of bringing Dominion laws into the discussion, thereby expanding the issue of Indian and fishing rights beyond the expressed provisions of the written treaties. In terms of content, the substance of the negotiations moved beyond the treaty foundation of the 1926 agreement.

At this time, the Department of Indian Affairs relied on Dominion legislation to protect livelihood interests of prairie Indians, including the signatories to Treaties 1 and 2 located in southern Manitoba. In this memorandum, Scott re-stated that para. 9 "as contained in the Alberta Agreement seems to me to preserve whatever rights the Indians may now enjoy in respect to hunting and fishing." ${ }^{170}$ However, the fact that he admitted that the Department did not oppose the application of provincial game laws, the necessity of the linkage between s. 69 of the Indian Act and treaties, the uncertainty of paramount Dominion jurisdiction with respect to Indian hunting and the use of the expression "whatever rights" together suggest that the Department's concept of Indian hunting rights was somewhat multi-faceted and ambiguous.

An intention to secure Indian livelihood existed; however, treaty rights, Dominion legislation, and paramount powers limiting the application of provincial games laws were intertwined. Significantly, neither treaties nor game regulations effectively protected Indian incomes from encroachment. Because of encroachment by outside hunters in northern Manitoba, Scott suggested a change and an improvement over the wording in the 1926 Alberta agreement:

\footnotetext{
I may say that with the development of the country and the entry of outsider hunters and trappers into the northern regions of the Province where the Indians rely almost entirely upon game for their subsistence, their plight is becoming more desperate year by year with the disappearance of game and while, as I stated, I think that the Indians in these regions have the full rights granted by treaties it is a question in my mind as to whether it would not be advisable to have it now clearly set forth in this agreement that the Indians in these northern regions shall have the right to take game at all times for their subsistence, and I should like to discuss this matter with you before the agreement is finally completed. ${ }^{171}$
}

Due to the absence of written livelihood rights in Treaties 1 and 2, the situation in Manitoba was more complicated than that in Alberta. The geographical observation that northern Manitoba Treaty Indians held expressed livelihood rights further complicate our search for intent. By bringing up the issue of year-long subsistence needs, he once again attempted to secure pragmatically the livelihood of northern Indians. Closed seasons on hunting and fishing restricted the ability of those living an Aboriginal mode of life to feed themselves. Scott seemed to separate year-round hunting and fishing for food from treaty rights. And rightly or wrongly, he was most concerned about northern Indians dependent upon the traditional economy and not as concerned about the Treaty 1 and 2 Indians of southern 
Manitoba. His request to do better than the 1926 agreement was based on the needs of northern Indians.

Acting Deputy Minister Chisholm not only acknowledged, but also took care to summarize Scott's correspondence of 4 September and thus, we have a record of how his proposals were understood by the Justice Department. On 6 September 1929, Chisholm wrote:

I note also your observations with regard to the privileges of hunting and fishing the Indians are now entitled to under Dominion Laws, and that with respect to the northern regions of the Province where the Indians rely almost entirely upon the game for their subsistence, it is a question in your mind whether it would not be advisable to have it now clearly set forth in this agreement that the Indians in those regions shall have the right to take game at all times for their subsistence. I shall bear in mind your desire to discuss this matter with me before the agreement is finally completed. ${ }^{172}$

Significantly, Chisholm associated hunting and fishing rights with Dominion laws and he paid no attention to the issue of Treaties 1 and 2. Apparently, Scott did not dispute Chisholm's summary. On 24 September 1929, somewhat belatedly, the Deputy Minister of Interior W.W. Cory forwarded an extract of Scott's memorandum to D.G. McKenzie, ${ }^{173}$ Minister of Mines and Natural Resources for Manitoba. ${ }^{174}$ By the third week of September both parties to the agreement had Scott's view on Indian hunting and fishing.

On 7 October 1929, Scott was sent a preliminary draft of the Manitoba agreement that reproduced the same hunting rights clause as appeared in the 1926 Alberta agreement. Significantly, the text of this particular draft Manitoba agreement was qualified with a typed annotation acknowledging that: "Dr. Scott's question as to the advisability of granting Indians in northern Manitoba the right to take game at all times for their subsistence has not yet been settled." ${ }^{175}$ By early October 1929, Scott had made his argument, but the drafters of the agreement had not given up on the language used in the 1926 Alberta agreement (see Appendix B). The acknowledgment of a possible change to the use of para. 8 of the 1926 agreement was based on Scott's concern for year-round hunting for northern Indians and not on concern over the deficiencies in Treaties 1 and 2 . His views were juxtaposed against the treaty rights wording of the 1926 agreement. In the covering letter, Deputy Minister Cory advised Scott that a note had been made "of your point on the possible advisability of granting to the Indians in northern Manitoba the right to take game at all times for their subsistence, so that this matter may not be overlooked." ${ }^{176}$ In Chisholm's summary of Scott's proposal of 4 September, the reservation on the draft agreement of early October 1929, and

Memorandum, Chisholm to Scott (6 September 1929) Ottawa, NAC (RG 10, vol. 6820, file 492-4-2, pt. 1).

Donald Gordon McKenzie, member of United Grain Growers; Secretary-Treasurer for United Farmers of Manitoba (1922-1926); member of Advisory Board on Tariff and Taxation (1926-1928); sworn in as Minister of Mines and Natural Resources and Provincial Secretary (22 October 1928); elected to Legislative Assembly of Manitoba (10 November 1928), as cited in A.L. Normandin, ed., The Canadian Parliamentary Guide: 1932 (Ottawa: Mortimer, 1932) at 405.

Letter, Cory to McKenzie (24 September 1929), Ottawa, NAC (RG 10, vol 6820, file 492-4-2, pt. 1).

Scott was provided with a copy of this covering letter.

Draft Manitoba agreement (ca. 7 October 1929), Ottawa. NAC (RG 10, ibid.).

Memorandum, Cory to Scott (7 October 1929). Ottawa. NAC (RG 10, ihid.). 
in Cory's covering letter of 7 October, the issue of year-round hunting in northern Manitoba and not the perceived "deficiencies" of Treaties 1 and 2 was indicated.

Scott's suggestion for additional protection for specifically northern regions renewed his disagreement with Bigger. After discussions with representatives from Manitoba, Biggar did not believe that it was practical to capture Scott's concern unless somehow a provision was made that would allow the Superintendent General of Indian Affairs to declare exempt, from time to time, particular geographical areas of Manitoba, so that provincial laws should "not apply to game killed by Indians for their own subsistence." 177 Obviously, the desire to protect Indian livelihood in northern regions introduced a geographical qualification, thereby creating some complexity during the negotiations. It might have been difficult to express Scott's concern for the livelihood needs of northern Indians in language that replicated s. 69 of the Indian Act but, significantly, Biggar did not dispute the validity of Scott's perception of the Indians' needs or of the desire for such protection. However, in keeping with the position he took in 1925 and 1926, Biggar was reluctant to make an expressed agreement about Indian livelihood. Instead, he suggested that "even if it were considered advisable to make an express agreement at the present time, this might perhaps better be covered by the exchange of letters than by inclusion in the formal document which is to provide for the transfer to the Province of its natural resources, and must be confirmed by Provincial, Dominion and Imperial statutes." ${ }^{178}$ Clearly, the content and wording would be shaped by the resolving of differences between federal participants charged the drafting of the agreement.

In the face of Biggar's objection, Scott appeared to back off, on 28 October 1929, he wrote:

In reply I beg to say that it does not appear that any good purpose will be served by the inclusion of such a provision in this transfer. Our contention is, as pointed out in my letter above referred to [4 September], that the Indians, according to the terms of treaties made with them, have such rights already without any special agreement with the Province, although such rights have not been insisted on. Since, however, the plight of the Indians in the northern regions of the Province is now becoming desperate with the disappearance of game due in part to the influx of white trappers, it is considered that the Indians should no longer be prevented from exercising these rights and that it would be appropriate to have these rights emphasised in the transfer of the Natural Resources. If the Dominion Government is not disposed to insist on such a provision, I can only suggest that the Department will have to be content with a provision similar to the provisions of Section 9 of the Alberta Agreement which is embodied in the draft Agreement with Manitoba as Section $10 .^{179}$

In effect, Scott was attempting to pragmatically ensure that Indians, especially northern Indians dependent upon a traditional livelihood, would have access to subsistence resources. In response to Biggar he reverted to treaty rights. Clearly, he did not seek any modifications to treaty rights; rather, he advocated an emphasis of treaty rights in preparation for the transfer. Because provincial laws did not protect Indians from an influx of disruptive White trappers, the Department no longer opposed the exercise of livelihood rights in opposition to provincial laws. He was also attempting to protect northern Indians from the conservation 
problems created by others. Scott neither seems to be unduly concerned about the source of the right, nor does he advocate a particularly restrictive definition of Indian. If such improvements could not be accommodated, Scott was willing to accept the language of the 1926 agreement. It was a fall-back position because he was looking for something more. He did not comment on Biggar's suggestion to cover the issue through an exchange of letters. ${ }^{180}$

Biggar did not engage Scott on this topic, but instead asked for "a copy of the clause of each of the treaties with Western Province Indians by virtue of which they are given special hunting and fishing rights not necessarily shared by all the residents of the province" because "the phraseology of these clauses may be material and it may be advantageous in the course of negotiations formally to put on record the nature of the rights arising under them which you consider it advisable to emphasize." ${ }^{\prime 81}$ Until this point, the intention of the negotiators was, at the very least, to ensure hunting rights for Treaty Indians. But with respect to hunting rights, in the discussion that followed the 1926 agreement, Scott placed an emphasis on Indians dependent upon the traditional livelihood. Biggar's desire to see all the western treaties indicates the need to consider variations in the wording of livelihood rights. Scott was concerned about protecting Indian livelihood rights in general in light of the failure of provincial conservation laws to provide protection to Indians from White trappers, whereas Colonel Biggar's point of reference was the existing regulatory framework. Scott's concern about scarcity created by outside trappers may have informed the object of the livelihood provision: "in order to secure to the Indians of the Province the continuance of the supply of game and fish." 182

On 14 November 1929, Scott responded to Biggar's request for a copies of the Prairie Treaties:

Re: Manitoba Natural Resources.

I have to acknowledge your letter of the 31 st ultimo asking for a copy of the clauses of each of the treaties with Western Province Indians by virtue of which they are given special hunting and fishing rights.

In reply I beg to say that the Province of Manitoba is covered by what are known as Treaties Nos. 1, 2, 3, 4, and 5. The first two have no provision respecting game. I am enclosing a copy of the clauses in Treaties 3, 4 and 5 dealing with the matter of hunting and fishing. I am also enclosing a sketch or plan showing approximately the areas covered by each of these five treaties. ${ }^{18.3}$

Here, Scott drew attention to the absence of hunting rights in Treaties 1 and 2 of southern Manitoba. His response focused on the treaties relating to Manitoba, thereby indicating that the discussion of these issues was with Manitoba and not with Alberta.

180 Ibid.

181 Memorandum, Biggar to Scott (31 October 1929), Ottawa, NAC (RG 10, ibid.).

1*2 See para. 12 of NRTA, supra note 6.

18.3 Memorandum, Scott to Biggar (14 November 1929), Ottawa, NAC (RG 10, vol. 6820, file 492-4-2, pt.

1). This document also indicates that the negotiations with Manitoba formed the lead agreement in 1929. 
The final negotiations for the Manitoba agreement occurred between 9 and 14 December. ${ }^{184}$ Mackenzie King recorded that a cabinet meeting was held in the morning to review a version of the agreement which had been drafted by Stewart's officers, Biggar and Hudson, who was a solicitor for the Province. He also noted that Solicitor General Cannon had made important contributions to the preamble and that "[i]t took us till one o'clock [from 11:00 AM] \& again from 2:30 till three to complete the first revision." ${ }^{185}$ The Prime Minister also recorded the first meeting of the concluding round of negotiations:

At 3 we were met by Premier Bracken, Mr. Hudson \& Mr. Major (Atty. Genl.) Manitoba whom I invited to come into our Cabinet Council room. We were joined by Cory [Interior Deputy Minister] \& Duncan Campbell Scott \& Col. Biggar. We spent the balance of the afternoon going over the agreement a second time, taking up points raised by Manitoba, and raising the points we had raised this morning. There does not appear to be anything very serious in the way of difference between us. ${ }^{186}$

Significantly, Duncan Campbell Scott participated in the negotiations with the Dominion and Manitoba ministers of the Crown and other officials.

Bigger provided Scott with a draft of what eventually became para. 13 of the Manitoba agreement (para. 12 in the Alberta and Saskatchewan agreements) on 12 December, together with the laconic covering letter, "[t]hese are the clauses about which I spoke to you last night." 187

15. [13] In order to secure to the Indians of the Province the continuance of the supply of game [unreadable] for their support and subsistence, Canada agrees that the laws respecting game in force in the Province from time to time shall apply to the Indians within the boundaries thereof, provided, however, that the said Indians shall have the right, which the Province hereby assures to them, of hunting. trapping and fishing game for food at all seasons of the year on all unoccupied Crown lands and on any other lands to which the said Indians may have a right of access. ${ }^{188}$

The original version referred to game, but not to fish. Handwritten annotations to this draft indicate the suggestion from Scott to include fish.

15. In order to secure to the Indians of the Province the continuance of the supply of game + fish for their support and subsistence. Canada agrees that the laws respecting game + fish in force in the Province from time to time shall apply to the Indians within the boundaries thereof, provided, however, that the said Indians shall

At this time, officials and Ministers representing the Province of Alberta were also present in Ottawa. Laird indicated that he met with Manitoba and Dominion officials on 9. 10, and 11 December. Apparently, a printed agreement had been ready by the end of November (see Memorandum. Laird to R. Perison. Acting Secretary, Canadian Committee (29 November and 16 December 1929). Winnipeg. AM, HBCA (RG 2/7/437). Similarly, Mackenzie King's diaries indicate that his involvement in linal round of negotiations and drafting began on the 9 th and ended on the 13th (King Diaries, supra note 1 (9 to 13 December 1929)).

185. King Diaries, ibid. (9 December 1929).

186 Ibid

187 Memorandum, Biggar to Scott (12 December 1929), Ottawa, NAC (RC 10, vol. 6820), filc 492-4-2, pt. 1).

Ixx Since Biggar's covering letter of 12 December 1929 referred to the preceding evening 's conversation. the date of 11 December is appropriate for this version of the livelihood rights provision (Draft Manitoba agreement (ca. 11 December 1929), reproduced in ()tawa. $N \wedge C^{\prime}(\mathrm{R}(i$ 10. ihid.)). 
have the right, which the Province hereby assures to them, of hunting, trapping and fishing game + fish for food at all seasons of the year on all unoccupied Crown lands and on any other lands to which the said Indians may have a right of access. ${ }^{189}$

Two of the recommendations requesting the insertion of the word "fish" were made to the text that was used in the final agreement. The suggestion to specify fish with respect to provincial laws was not incorporated into the final text, which would comport with the notion of federal legislative authority over freshwater fisheries. Evidently, Scott's letter of 4 September 1929 resulted in a major re-thinking of the Indian interests and needs with respect to access to resources for traditional pursuits and to the scope of provincial regulatory authority (see Appendix C). The wording of the 1926 Alberta agreement was abandoned and the right was redrafted.

An interesting development in relation to the livelihood rights clause occurred prior to 12 December 1929, when the word "trapping" was added. David H. Laird provided an interpretation of the livelihood right in the 14 December 1929 Manitoba agreement for the HBC: "Clause 13 [15] relates to the application of the Provincial Game Laws to the Indians, and assures to them the treaty rights of hunting, trapping and fishing. As originally drafted this did not include trapping, and this was inserted at my request." ${ }^{\prime 90}$ Apparently, Laird did not appreciate the rewriting of the 1926 provision, as he interpreted para. 12 of the final agreement as an assurance of treaty rights. He did not indicate any derogation of the original treaty rights nor that commercial rights had been extinguished; in fact, he suggested that the intent was to assure existing rights. As a third party participant, Laird's records provide no support for the notion that rights were reduced. As compared to the 1926 Alberta agreement, para. 12 better reflected the mixed aspects of the traditional economy.

\section{REDEFINING INDIANLIVELIHOOD RIGHTS: THE 1926 AND 1929 AGREEMENTS COMPARED}

Although the 1926 Alberta agreement did not come into effect on its own, it provided the basis for many of the terms of the final agreement with respect to wide-ranging trusts, and obligations arising from the manner and conditions under which the Dominion authorities had previously alienated lands and resources in the three Prairie Provinces. A notable exception to the understanding of the other terms of the agreements concerned Indian interests.

Nonetheless, similarities and connections between other provisions in the 1926 and 1929 agreements are indisputable. The 1926 agreement provided a framework for lands, trusts, and obligations. A memorandum of an interview on 27 August 1929 between Manitoba representatives Honourable D.G. McKenzie and R.W. Craig and Dominion officials Minister of the Interior Charles Stewart and Acting Deputy Minister Mr. Roy A. Gibson recorded that "[i]t was generally agreed that following the basis of the award of the Manitoba Resources Commission, the balance of the terms of the agreement would be along the lines of the agreement (12 December 1929), Ottawa, NAC (RG 10, ibid.)). These changes can be found in the sixth proof with the date 12-12-29, a copy of which is found in Winnipeg, AM (RG 17, Al, file 1). 
agreement signed by the Province of Alberta in January, 1926, insofar as these terms are applicable." 191 In effect, the 1926 Alberta agreement identified trusts and obligations for the purposes of the 1929 negotiations. Also at this August meeting, para. 9 of the 1926 agreement, the provision concerning Treaty Indian hunting, was specifically agreed to by Dominion and Manitoba representatives. Clearly, the 1926 agreement between Alberta and Canada was a significant draft document, which led up to the 1930 statutes that affected the transfer of resources. Thus, the final 1929 agreement and the 1926 agreement between Alberta and Canada are strongly linked. Appendix D depicts the major shifts in the development of the Indian livelihood rights paragraph. The 1929 negotiations between the Dominion and Manitoba and Alberta were conducted through the 1926 agreement. For these reasons, changes made in 1929 to the wording of the provision for Indian livelihood are essential considerations for understanding the intentions of the paragraph in the final agreement.

Recall that the paragraph providing treaty hunting rights in the 9 January 1926 agreement, having originated in a 1925 draft provision drafted by Scott and Bigger, stated:

\begin{abstract}
9. To all Indians who may be entitled to the benefit of any treaty between the Crown and any band or bands of Indians, whereby such Indians surrendered to the Crown any lands now included within the boundaries of the Province, the Province hereby assures the right to hunt and fish on all the unoccupied Crown lands administered by the Province hereunder as fully and freely as such Indians might have been permitted to so hunt and fish if the said lands had continued to be administered by the Government of Canada. ${ }^{192}$
\end{abstract}

This wording of the livelihood provision was still acceptable in early October 1929, but it came under serious review towards the end of October, as reflected in the exchange of correspondence between Biggar and Scott. ${ }^{193}$ At the same time, Scott succeeded at having a provision for Indian interest in surrendered reserve lands (para. 12) added to the 1929 agreement. This was accomplished by making reference to the 1924 Canada and Ontario agreement respecting Indian reserve lands (even though this entailed a statute giving effect to an agreement between Canada and a province that was not party to the transfer agreement). ${ }^{194}$ When the drafters of the agreement needed to clarify a complex issue, such as an Indian interest in reserve lands, a reference to the appropriate authority was made. In law, Indian interests in surrendered reserve lands were not secure, ${ }^{195}$ and the 1924 CanadaOntario agreement had provided a remedy for the problem of who held beneficial interests in Indian reserves in Ontario. Biggar's request for copies of all of the western treaties, the rewriting of para. 9 of the 1926 agreement, and the re-introduction of a provision for Indian

191 Memorandum of an Interview (27 August 1929), Winnipeg, AM (RG 17, A 1, file 1). This memorandum does not give the exact date of the January 1926 agreement. However, with respect to the Indian hunting provision, the wording of para. 12 does not change between 9 January 1926 and the agreement that was scheduled with the bill prepared for the House of Commons in March 1926. Although complicated by the school lands question, the agreement of 9 January 1926 was not an unfinished draft (see House of Commons Debates (18 February 1929) at 191).

$192 \quad 1926$ Alberta agreement, supra note 145

193. See supra notes 177-81.

$1 \% 4$ An Act for the settlement of certain questions between the Governments of Canada and Ontario respecting Indian Reserve Lands Act, S.C. 1924, c. 48.

195 See e.g. Quebec (A.G.) v. Canada (A.G.) (1920), 56 D.L.R. 373, [1921] 1 A.C. 401 (P.C.). This case is also known as "Re: Indian Lands." 
interest in surrendered reserve lands indicate that important Indian interests in the transfer were given serious consideration before the completion of the December drafts of the 1929 agreement.

The final wording employed by the 14 December 1929 agreement between Canada and Manitoba, and scheduled with the concurrent provincial, federal, and imperial statutes, provided:

13 [12]. In order to secure to the Indians of the Province the continuance of the supply of game and fish for their support and subsistence, Canada agrees that the laws respecting game in force in the Province from time to time shall apply to the Indians within the boundaries thereof, provided, however, that the said Indians shall have the right, which the Province hereby assures to them, of hunting, trapping and fishing game and fish for food at all seasons of the year on all unoccupied Crown lands and on any other lands to which the said Indians may have a right of access. ${ }^{196}$

The same wording is found in a typeset version of the Alberta agreement of 14 December 1929. ${ }^{197}$ These draft versions of the agreement, along with Indian Affairs correspondence, establish that the final version of the wording of the Indian livelihood rights provision was only taking shape by the second week of December.

Significant changes in wording and content occurred between the 9 January 1926 version of the Indian hunting right and the 14 December 1929 version. ${ }^{198}$ The expression "for food" was stipulated. Indian hunting could not be restricted through closed seasons since the wording "at all seasons of the year" was included. The range of hunting and fishing was expanded from unoccupied Crown lands to "any lands to which the said Indians may have a right of access." The issue of Dominion and provincial jurisdiction over Indian hunting was stated differently. Direct reference was made to provincial game laws instead. However, provincial laws were to continue a supply of game and fish for Indian support and subsistence. The need for year-long subsistence, a priority for Duncan Campbell Scott, was achieved and, perhaps also, the province acquired the obligation to ensure through conservation that the resources existed in order to secure a supply of game and fish to the Indians. Scott's desire to protect Indians from provincial game laws resulted in a major reworking of the language of the terminology used in para. 9 of the 1926 Alberta agreement. He did not achieve this by arguing for the exchange of some rights for other rights, but he was resolute in protecting Indian livelihood from the provincial government practice of imposing closed seasons on Indian hunting and fishing.

The 1929 version added the express category "trapping." The inclusion of trapping indicates a greater appreciation for the traditional way of life and this improvement can be

"An Agreement Between The Dominion Of Canada And The Province Of Manitoba: On the subject of" the Transfer Of The Natural Resources Of Manitoba" (Ottawa: F.A. Acland, 1926), 7th proof of the agreement (14 December 1929), a copy of which is found in Winnipeg. AM (RG 17, Al, file 1) [Manitoba agreement 7th proof (14 December 1929)].

Agreement Made On The Fourteenth Day Of December, 1929 Between The Dominion OfCanada And The Province Of Alberta On the Subject of the Transfer ()f The Natural Resources Of Alberta (Ottawa: F.A. Acland, 1929), a copy of which is found in Ottawa, NAC. public records of the Department of Indian and Northern Affairs (RG 22, vol. 17, file 70). 
attributed to HBC counsel David $\mathrm{H}$. Laird. That this change occurred at the behest of the Hudson's Bay Company, indicates that some provision for commercial activity was added to the paragraph after the stipulation "for food" had been made to the $1929 \mathrm{draft}$. Understandably, if there had been a clear and plain intent to eliminate all traces of a commercial right, then the word "trapping" would not have been added to the text of para. 12 at the behest of the HBC. The inclusion of trapping added a commercial dimension to para. 12.

However, a most significant change in the meaning of Indian occurred. The 1929 version, which became the wording in the subsequent Imperial, Dominion, and Provincial Acts provided a general reference to Indians by employing the expression "Indians of the Province." 199 The 1926 definition of Indian had identified a smaller population. In essence, the definition of Indian in the 1926 draft agreement is a Treaty Indian: "... Indians who may be entitled to the benefit of any treaty between the Crown and any band or bands of Indians, whereby such Indians surrendered to the Crown any lands." ${ }^{200}$ The stipulations of Indians treating with the Crown and with land surrenders to the Crown are essential to a definition of a Treaty Indian of the Prairie Provinces. In terms of the evolution of these agreements, the definition of Indian with respect to Indian resource rights was limited to Treaty Indians in the 1926 agreement. From other typeset drafts of the Manitoba agreement, it is clear that the Indian resource rights wording of the 1926 Alberta agreement were under consideration during the period of active negotiations late in 1929 (see Appendix B). ${ }^{201}$ We can appreciate that some time after 7 October, but most likely between 14 November and 10 December 1929 , the wording concerning Indian livelihood rights was consciously changed and that the definition of "Indians" acquired additional dimensions because the explicit references to treaties, land surrenders, and bands were dropped.

It would be rather questionable to imply that all of the changes to the category of beneficiaries of the livelihood rights provision was an effort to patch over the lack of expressed hunting and fishing rights of Treaties 1 and 2. Scott's correspondence of 4 September 1929 made the drafters aware of the omission of hunting and fishing in Treaties 1 and 2 . However, the 1926 version of the paragraph clearly provided for "all Indians who may be entitled to the benefit of any treaty" and this wording did not stipulate that it only applied to Treaty Indians with expressed treaty hunting and fishing rights. Consequently, the definition of Treaty Indians in the 1926 agreement applied to the Manitoba Indians belonging to Treaties 1 and 2 because these Indians did meet the simple requirement of being "entitled to the benefit of any treaty." In other words, it is more than a little incredulous to suggest that the 1926 wording with respect to treaties was abandoned so that Treaty Indians could be better covered by the more general category "Indians of the Province." Thus, the written "deficiencies" concerning hunting and fishing rights in Treaties 1 and 2 cannot explain empirically or analytically the replacement of the 1926 wording that covered a specific category of Indians (namely, Treaty Indians) with the more general category of Indians of the Province. In terms of the Manitoba agreement, Scott expressed real concerns about the situation of northern Indians who in fact were beneficiaries of Treaty 5, which included

201 See Winnipeg, AM (RG 17, Al, file 1) for evidence of a variety of drafts leading to the final agreement. 
expressed livelihood rights. Moreover, the correspondence between Scott, Chisholm, and Biggar in September 1929 demonstrated a shift in the underlying concept of the provision. The exhortation that the changes from the 1926 draft to the 1929 final wording concerns unique conditions in Manitoba is based on a selective use of the archival record. Instead, a comparison of the 1926 and 1929 versions, within the context of the written records, indicates that Scott's view prevailed.

For those seeking to restrict the right by limiting the number of beneficiaries, it is tempting to pull the Indian Act of $1927^{202}$ into a definition of Indian in the NRTA. For the Prairie Provinces, the category Status Indians identifies more beneficiaries than the category Treaty Indians. Without a reference to the definition of Indians in the Indian Act, Status Indians are not equivalent to Indians of the Province, although this is a closer representation of Indians of the Province than is the category Treaty Indians. Because the drafters of the agreement held the necessary competency to devise indispensable references to other authorities to assist with defining content, the conjecture that would somehow read the Indian Act into the Constitution Act, $1930^{203}$ for the purposes of restricting a right by opposing an understanding based on the plain meaning of the words is a highly speculative assertion. Paragraph 12 makes no reference to the Indian Act. In contrast, para. 11 concerned the question of reversionary rights in reserve lands and made reference to a statute in order to give substance to para. 12. As will be demonstrated, in the specific historical context of the Prairie Provinces in 1930, Indians of the Province was not congruent to Treaty Indians or Status Indians.

At this point, the comparison of the 1926 and 1929 agreements permits certain conclusions. The beneficiaries identified in 1926 are not identical to the 1929 beneficiaries; a change from Treaty Indians to Indians occurred. A fundamental change between 1926 and 1929 was that the group of beneficiaries was expanded. ${ }^{204}$ The change in the category of Indians can not be explained merely by reference to the situation of Indians of southern Manitoba. The necessity of using the expression Treaty Indian, a fairly common usage in respect to treaty rights, and certainly an important usage by Treaty Indians themselves, substantiates that in 1926 individuals belonging to the category "Non-Treaty Indian" were known to exist. The fact that in 1929 almost, but not every, Indian of the Province was a beneficiary of treaties, also allows for the possibility that some Indians of the Province were not Treaty Indians and this also means that a category of Indians existed who were not Treaty Indians. Non-Treaty Indians would not have the benefits of treaties. With respect to the early case law, the fact the individuals charged with violations of provincial game laws were also Treaty Indians does not prove that all Indians of the Province are Treaty Indians. If other Indian individuals or groups existed and qualified for inclusion as Indians of the Province, then Indians of the Province can not be used interchangeably with Treaty Indians and thus, by itself, the category Treaty Indian can not mean Indians of the Province. Simply put, all Treaty Indians are Indians of the Province, but not all Indians are Treaty Indians. Similarly, while all Treaty Indians are "Indian Act" Indians, not all Indian Act Indians are Treaty Indians. 
The removal of the restriction to Treaty Indian as beneficiaries of para. 12 has implicatioins for the nature of the right. Given that Indians of the Province was not and is not equal to Treaty Indians of the Province and given the fact that these categories are not interchangeable, there is a fatal fallacy in legal reasoning in attempting to apply the NRTA to specific incidents involving hunting and fishing - a point that shall be pursued more thoroughly in Part 2 of this article. Clearly, only Treaty Indians are the beneficiaries of treaty rights. If, and only if, Indians of the Province means exclusively Treaty Indians can there be a reasonable assertion that a clear and plain intention to modify a Treaty right existed in 1929.

\section{The Transfer of Fishing Rights to The Provinces}

The protection that might be afforded by the NRTA for Aboriginal livelihoods might be understood by considering not just para. 12, but also the provision for transferring the right of the fishery. The negotiations for the transfer of natural resources to the Prairie Provinces also entailed the question of the proprietary interests in freshwater or inland fisheries. The control and management of inland fisheries had been a matter of jurisdictional dispute between the Dominion and the Province of Ontario in the late nineteenth century. ${ }^{205}$ However, the absence of extensive archival records from the Department of Marine and Fisheries (Record Group 23) with respect to the transfer of resources indicates that fisheries officials were certainly less involved or less interested in drafting the agreement than officials from the Indian Affairs and Interior departments. Correspondence between the Departments of the Interior and Marine and Fisheries concerning the transfer was limited to issues concerning the provincial assumption of ownership and management of fish hatcheries, staff transfers, and the value of department assets located in the Prairie Provinces. ${ }^{206}$ Consequently, the records of Marine and Fisheries do not provide a very detailed historical context for reconstructing the policies that concerned transferring the right of the fishery to the Province. ${ }^{207}$ Again, it is instructive to reconstruct the drafting of this section of the agreement by beginning with the 1925 version of the 1926 Alberta agreement — that is, the material developed by Colonel Biggar.

When Biggar prepared his 1925 memorandum for Prime Minister Mackenzie King on the transfer of Alberta resources, Appendix L covered Protection of Fisheries. Fisheries officials provided a review of property and management issues, in different jurisdictions, related to s. 91 of the BNA Act, $1867^{208}$ — "Sea Coast and Inland Fisheries." Biggar noted pragmatically that "the protection of inland fisheries can conveniently be combined with the provincial game protection service." 209

On 4 June 1925, Biggar provided Deputy Minister of Marine and Fisheries A. Johnston a draft of the fisheries paragraph for the Alberta agreement. It stated:

See Lise C. Hansen, "Treaty Fishing Rights and the Development of Fisheries Legislation in (Intario; A primer" (1991) 7 Native St. Rev. 1 at 15-17. Ottawa, NAC (RG 23, vol. 1049, file 721-8-6 pt. 1).

Being para. 10 in the Manitoba agreement, supra note 4 and para. 9 in the Alberta agreement and Saskatchewan agreements, supra note 6.

Supra note 99.

Draft of Biggar's memorandum (ca. 1925), Ottawa, NAC (RG 23, vol. 1049, file 721-8-7, pt. I). 
All rights of fishery shall, after the coming into force of this agreement, belong to and be administered by the Province, and the Province shall have the right to dispose of all such rights of fishery by sale, license or otherwise, subject only to the exercise by the Parliament of Canada of its legislative jurisdiction over sea-coast and inland fisheries. 210

Johnston agreed with this draft, but suggested that "[w]ould it not be well, however, for the agreement, if such is entered into, to state specifically that the Province will take over the responsibility for the protection and development of the fisheries."211 On its own and in this form, the transfer of "all rights of the fishery" to the provinces could be threatening to Aboriginal and Treaty fishing rights. By early July, the entire agreement was provided to the Minister of Marine and Fisheries, and Johnson's suggestion to make specific the province's responsibility to protect and to develop fisheries was added. In July 1925, the draft agreement provided:

6. The interest of the Crown in the waters within the Province under The Northwest Irrigation Act, 1898, being chapter thirty-five of sixty-one Victoria, as reserved by section twenty-one of The Alberta Act, shall continue to be vested in the Crown and administered by the Government of Canada for the purposes of Canada.

7. Notwithstanding the provisions of the last preceding clause, all rights of fishery, except such as are hereafter specified, shall, after the coming into force of this agreement, belong to and be administered by the Province, and the Province shall have the right to dispose of all such rights of fishery by sale, licence or otherwise, subject only to the exercise by the Parliament of Canada of its legislative jurisdiction over sea-coast and inland fisheries; the Province will be responsible for the protection and development of the fisheries hereby transferred to it. $^{212}$

Johnston responded to this draft on 7 July 1925:

I do not know that I appreciate the reasons for 'except such as are hereafter specified' in [para.] 7. Primarily the purpose that I had in mind was that the transfer of the Fisheries to the Provincial authorities would result in lessening the expense of the Government. In order to obtain that result, it seems to me unnecessary to make any exceptions. $^{213}$

Biggar responded: "The exception to which you refer is intended to cover the retention of the fisheries in the parks. The agreement provides that these shall not pass." ${ }^{214}$ In the July 1925 draft of what became the 1926 Alberta agreement, national parks were covered in paras. 12 to 16 and followed the paragraph on fishing. Hence, for that single purpose, the use of herein was appropriate.

In the final 1926 Alberta agreement, the provision for transferring fishing rights was grouped under the heading "Water and Fisheries." The two paragraphs were related:

6. The interest of the Crown in the waters within the Province under The Northwest Irrigation Act, 1898, being chapter thirty-five of sixty-one Victoria, as reserved by section twenty-one of The Alberta Act, and in the land 
forming the bed or shore of any lake, stream or body of water, shall continue to be vested in the Crown and administered by the Government of Canada for the purposes of Canada.

7. Notwithstanding the provisions of the last preceding clause, all rights of fishery, except such as are hereafter specified, shall, after the coming into force of this agreement, belong to and be administered by the Province, and the Province shall have the right to dispose of all such rights of fishery by sale, licence or otherwise, subject only to the exercise by the Parliament of Canada of its legislative jurisdiction over sea-coast and inland fisheries; the Province will be responsible for the protection and development of the fisheries hereby transferred to it. ${ }^{215}$

The ownership and administration of beds and shores was to remain with the Dominion. The management of the right of the fishery was transferred to the province. With that transfer, the province became responsible for the protection and development of the fisheries. Legislative authority remained with the Dominion. With the use of the expression "except such as hereafter specified," the agreement provided limitations on the transfer of rights of the fishery to the province. Paragraph 9 of the 1926 agreement provided for Indian livelihood rights. Significantly, the paragraph providing a recognition of the Hudson's Bay Company's interests preceded the fishing paragraph.

With respect to the right of the fishery, the 1929 negotiations between Manitoba and the Dominion began by following the text of the 1926 Alberta agreement. The draft Manitoba agreement did not make reference to The Northwest Irrigation Act, 1898. ${ }^{210}$ Instead, the early October draft recognized that Crown rights in river beds, shorelines, and such would be administered by the Dominion. ${ }^{217}$ Otherwise, at this point, the wording of the fisheries paragraph, like that of many of the provisions of the October draft, was identical to that found in the 1926 Alberta agreement.

Before finalizing the 14 December 1929 agreement, changes were made to the language used for transferring the right of the fishery employed by the 1926 agreement and that employed by the early October 1929 draft agreement. In the 1929 Manitoba Agreement, the "Water and Fisheries" paragraphs were placed under separate headings. ${ }^{218}$ The provision for maintaining Dominion rights in shores and river beds was removed. Thus, by 14 December 1929 the fishery rights paragraph no longer recognized Dominion Crown rights in shorelines and river beds. It now provided:

10. Except as herein otherwise provided, all rights of fishery shall, after the coming into force of this agreement, belong to and be administered by the Province, and the Province shall have the right to dispose of all such rights of fishery by sale, licence or otherwise, subject to the exercise by the Parliament of Canada of its legislative jurisdiction over sea-coast and inland fïsheries. ${ }^{219}$

1926 Alberta agreement, supra note 145; the reference to The Northwest Irrigation Act, 1898, Vict. 61, c. 35 and to the Alberta Act, supra note 61 are worth noting.

Northwest Irrigation Act, ibid.

Draft Manitoba agreement (ca. 7 October 1929), Ottawa, NAC (RG 10, vol. 6820, file 492-4-2, pt. I). The final 1929 agreement made specific reference to the development of hydro power on the Winnipeg River basin and section of the Dominion Water Power Act. 1927. R.S.C. 1927, c. 210 was repealed with respect to Manitoba.

Manitoba agreement 7th proof (14 December 1929), supra note 196 [emphasis added]. 
With respect to the fishing right, the use of "hereafter" in the 1926 Alberta agreement was changed to "herein" in the 1929 final agreement. Effectively, the limitation on the transfer of the fishery to the province was broadened so that the entire agreement became relevant. The express provision identifying the Province's responsibility "for the protection and development of the fisheries" was dropped.

Once again, HBC legal advisor David H. Laird seemed to have played a role in effecting changes to the agreement. In his 16 December 1929 Memorandum to Company officials, Laird explained:

Clause 10 relates to fisheries. In its original form it appeared objectionable as it transferred to the Province "all rights of fishery." The Company may have fishery rights in certain lakes or waters. To meet this objection, the phrase "except as herein otherwise provided" was inserted, and if the Company has any such rights, it will be protected by the combined effect of clause 5 and $10 .^{220}$

A comparison of the 1926 Alberta agreement and the 14 December 1929 agreement merely affirms that "herein" was substituted for "hereafter." Given the sponsor, such a distinction had implications for the HBC and perhaps also for Aboriginal peoples. Since the HBC interests were affirmed in para. 4 of the draft that preceded the "hereafter" in the earlier agreements, the limitation on the transfer of the right would have had no effect with respect to $\mathrm{HBC}$ interests.

The context provided by Laird with respect to the intent of the fishery rights paragraph demonstrates that the drafters of the agreement were willing to incorporate limits on Manitoba's right of the fishery based on the concerns of non-Crown interests. His desire to protect any rights that the Company might have held in certain lakes and waters was expressed by the intention to limit provincial control over the fishery, which he found objectionable as it had been stated originally. Laird himself was not aware of whether or not the Company had any specific fishing rights, but that did not prevent the drafters from heeding to Laird's request. In effect, customary uses of fisheries by the HBC were given consideration by this change in intent. The intervention by Laird in the drafting of the fishery rights paragraph also indicates that the expression "[e]xcept as herein otherwise provided" was not a mere boilerplate expression; rather, it was consciously intended to be understood and read with all of the other sections of the agreement. The change from hereafter to herein was not a minor or insignificant change. It expanded the terms of reference for the limitation of the transfer of the right of the fishery to the province beyond the original intention with respect to fisheries management in national parks, as provided for in the 1926 Alberta agreement. In terms of the use of fisheries, both the rights of the HBC and Indian livelihood rights are relevant sections of the agreement. Thus, the addition by Scott of "fish" to the 12 December draft of para. 12 conformed with the limitation placed on provincial fishing rights.

Unless the "herein" limitation is appreciated and acknowledged, the transfer of all fishing rights could be quite threatening to Aboriginal fishing rights. This change indicates that with respect to issues concerning fishing resources, paras. 10 and 12 need to be read together. The 
acknowledgment accorded by the drafters of pre-existing fishing interests in the final agreement is consistent with a general limit placed on the transfer of resources to the provinces. The term that effected the "Transfer of Public Lands Generally" provided: "the interest of the Crown in all Crown lands ... belong to the Province, subject to any trusts existing in respect thereof, and to any interest other than that of the Crown in the same."221 Prior to the drafting of the agreement, the intention to protect existing interests and trusts was provided for in the Order-in-Council that established the Royal Commission on the natural resources of Manitoba, Privy Council Order 1258 (1 August 1928):

5. Upon agreement on the financial terms following consideration of the report of the commission, the respective Governments to introduce the necessary legislation to give effect to the financial terms as agreed upon, and to effect the transfer to the province of the unalienated natural resources within its boundaries, subject to any trust existing in respect thereof, and without prejudice to any interest other than that of the Crown in the same. ${ }^{222}$

Recognition of existing trusts and interests was affirmed in the Order-in-Council that established a process that resolved the old problem of Dominion control over natural resources of the Prairie Provinces and in the final agreements that were put into effect by statutes in 1930. The change from "hereafter" to "herein" modified the original intent of para. 9 (the transfer of the right of the fishery to the province) as it was meant to be understood as giving consideration to other specific and general rights, interests, and obligations involved in the transfer of natural resources. If, for instance, Aboriginal rights or treaties were a "trust," then the transfer of the right of the fishery to the province is not only contingent on HBC interests (para. 4) and national parks (paras. 14, 15, and 16); it would be reasonable to subject the provincial right of the fishery to such Aboriginal and Treaty rights as existed in 1930. It is doubtful that the customary use of fish by the HBC that Laird was seeking to protect surpassed the use of fish by Aboriginal people. Similarly, the references to "fish" in para. 12 are often regarded as somewhat meaningless (because fisheries regulations were federal jurisdiction). However, it would seem that para. 12 may place a limitation on the provinces' unfettered right of fishery. ${ }^{223}$ Previous efforts to discern Indian rights related to traditional livelihood in para. 12 have been somewhat flawed because the effort has been focused exclusively on para. 12 and because that paragraph has not been read with the assistance of paras. 1 and 10 .

\section{HiSTORICAL RECONSTRUCTION OF THE NRTA SUMMARIZED}

This first part of this analysis has provided a detailed reconstruction of the historical circumstances in which the NRTAs were created. From this perspective, as demonstrated by the question of the provincial right of the fishery, archival records are a fundamental source of information about the intent of the drafters, thereby suggesting a more insightful reading of the plain text of the agreement. To my knowledge, the legal effect of the "herein" limitation of the provincial fishing right has never been considered, perhaps because this

$221 \quad$ See the Manitoba agreement, supra note 4 at para. 1.

$222 \quad$ P.C. 1258 (1 August 1928), reproduced in the Manitoba Report, supra note 71 at 5

$223 \quad$ In a decision regarding fishing. it was held that the para. 13 of the NRTA, supra note 6 did not excmpt Indians from prosecution under the Fisheries Act, R.S.C. 1985, c. F-14 (see R. v. Fontaine (1978), 43 C.C.C. (2d) 385, [1979] 2 C.N.L.R. 79 (Man. Prov. J. (.t. (Crim. Div.)). 
"herein" is better appreciated when the motives for changing "hereafter" to "herein" are known. While those responsible for devising the livelihood right did not understand rights as did Aboriginal peoples of the time or as we do today, it is evident that considerable effort went into para. 12 and that it was not some haphazard afterthought. Unlike previous considerations of hunting and fishing rights, para. 12 is now situated in the political and legal context of the times. The possible legal significance of this previously unacknowledged, yet intricate, history will be demonstrated in Part 2.224

There is no historical evidence that a derogation of treaty livelihood rights was intended or occurred and, in fact, the actual needs for those living the Indian mode of life became a priority in December 1929. An examination of the 1926 Alberta agreement provides a necessary reference for appreciating a shift away from treaty hunting rights. In the process of refashioning the hunting right as a livelihood right, the drafters defined the beneficiaries as "Indians of the Province."

For the purposes of rights litigation, anchoring an analysis in historical records is not a trivial task. The establishment of the relationship between history and law for issues involving Aboriginal and Treaty rights conflicts is incomplete in many respects, although the relevance of archival records is increasingly appreciated. To the extent that history can assist the courts, more is entailed than the simple submission of archival documents as mounds of exhibits. Without the capacity of both parties to engage in rigorous historical analysis, the prospect of a misapprehension of history exists. Thus, Part 2 will take issue with "historical" assertions that "Indians of the province" means simply Indian Act Indians and that the reworking of the 1926 hunting right was necessitated by deficiencies in Treaties 1 and 2 . Similarly, the argument that the extrinsic evidence detailing the drafting of para. 12 is irrelevant for the purposes of the law will be explored. As Part 2 will demonstrate, serious disagreement about the meaning of Indians in para. 12 surfaced shortly after the enactment of the agreements and that the ensuing records provide vital insights or at least confirm Mackenzie King's observation that "[i]t is characteristic of lawyers that as soon as they conclude an agreement, they begin to find the need of discovering what its terms mean."225 


\section{Draft}

10. To all Indians who may be entitled to the benefit of any treaty between the Crown and any band or bands of Indians, whereby such Indians surrendered to the Crown any lands now included with the boundaries of the Province, the Province hereby assures the right to hunt and fish on all the unoccupied Crown lands administered by the Province hereunder as fully and freely as such Indians might have been permitted to so hunt and fish if the said land continued to be administered by the Government of Canada.

\section{Alberta/Canada agreement}

9. To all Indians who may be entitled to the benefit of any treaty between the Crown and any band or bands of Indians, whereby such Indians surrendered to the Crown any lands now included with the boundaries of the Province, the Province hereby assures the right to hunt and fish on all the unoccupied Crown lands administered by the Province hereunder as fully and freely as such Indians might have been permitted to so hunt and fish if the said land continued to be administered by the Government of Canada.

\section{House of \\ Commons Bill}

9. To all Indians who may be entitled to the benefit of any treaty between the Crown and any band or bands of Indians, whereby such Indians surrendered to the Crown any lands now included with the boundaries of the Province, the Province hereby assures the right to hunt and fish on all unoccupied Crown lands administered by the province hereunder as fully and freely as such Indians might have been permitted to so hunt and fish if the said land continued to be administered by the Government of Canada. 


\section{Alberta/Canada agreement}

9. To all Indians who may be entitled to the benefit of any treaty between the Crown and any band or bands of Indians, whereby such Indians surrendered to the Crown any lands now included with the boundaries of the Province, the Province hereby assures the right to hunt and fish on all the unoccupied Crown lands administered by the Province hereunder as fully and freely as such Indians might have been permitted to so hunt and fish if the said land continued to be administered by the Government of Canada.

\section{Early draft of Manitoba agreement}

10. To all Indians who may be entitled to the benefit of any treaty between the Crown and any band or bands of Indians, whereby such Indians surrendered to the Crown any lands now included with the boundaries of the province, the Province hereby assures the right to hunt and fish on all unoccupied Crown lands administered by the Province hereunder as fully and freely as such Indians might have been permitted to so hunt and fish if the said land continued to be administered by the Government of Canada.
Early draft of Manitoba agreement

10. To all Indians who may be entitled to the benefit of any treaty between the Crown and any band or bands of Indians, whereby such Indians surrendered to the Crown any lands now included with the boundaries of the Province, the Province hereby assures the right to hunt and fish on all the unoccupied Crown lands administered by the Province hereunder as dully and freely as such Indians might have been permitted to so hunt and fish if the said land continued to be administered by the Government of Canada. (Note: Dr. Scott's suggestion as to the advisability of granting Indians in northern Manitoba the right to take game at all times for their subsistence has not yet been settled.)

\section{January-March} 1926

\section{August 1929}

\section{October 1929}


15. [13] In order to secure to the Indians of the Province the continuance of the supply of game [resources?] for their support and subsistence, Canada agrees that the laws respecting game in force in the Province from time to time shall apply to the Indians within the boundaries thereof, provided, however, the said Indians shall have the right, which the Province hereby assures to them, of hunting, trapping and fishing game for food at all seasons of the year on all unoccupied Crown lands and on any other lands to which the said Indians may have a right of access.
15. [13] In order to secure to the Indians of the Province the continuance of the supply of game and fish for their support and subsistence, Canada agrees that the laws respecting game and fish in force in the Province from time to time shall apply to the Indians within the boundaries thereof, provided, however, that the said Indians shall have the right, which the Province hereby assures to them, of hunting, trapping and fishing game and fish for food at all seasons of the year on all unoccupied Crown lands and on any other lands to which the said Indians may have a right of access.
13. In order to secure to the Indians of the Province the continuance of the supply of game and fish for their support and subsistence, Canada agrees that the laws respecting game in force in the Province from time to time shall apply to the Indians within the boundaries thereof, provided, however, that the said Indians shall have the right, which the Province hereby assures to them, of hunting, trapping and fishing game and fish for food at all seasons of the year on all unoccupied Crown lands and on any other lands to which the said Indians may have a right of access. 


\section{Alberta/Canada agreement}

9. To all Indians who may be entitled to the benefit of any treaty between the Crown and any band or bands of Indians, whereby such Indians surrendered to the Crown any lands now included with the boundaries of the Province, the Province hereby assures the right to hunt and fish on all the unoccupied Crown lands administered by the Province hereunder as fully and freely as such Indians might have been permitted to so hunt and fish if the said land continued to be administered by the Government of Canada.

January-March 1926

\section{Early Draft of Manitoba agreement}

10. To all Indians who may be entitled to the benefit of any treaty between the Crown and any band or bands of Indians, whereby such Indians surrendered to the Crown any lands now included with the boundaries of the Province, the Province hereby assures the right to

hunt and fish on all the unoccupied Crown lands administered by the Province hereunder as fully and freely as such Indians might have been permitted to so hunt and fish if the said land continued to be administered by the Government of Canada.

Fall 1929
13. In order to secure to the Indians of the Province the continuance of the supply of game and fish for their support and subsistence.

Canada agrees that the laws respecting game in force in the Province from time to time shall apply to the Indians within the boundaries thereof, provided, however, that the said Indians shall have the right, which the Province hereby assures to them, of hunting, trapping and fishing game and fish for food at all seasons of the year on all unoccupied Crown lands to which the said Indians may have a right of access.

12 December 1929

10 July 1930
13. In order to secure to the Indians of the Province the continuance of the supply of game and fish for their support and subsistence, Canada

agrees that the laws respecting game in force in the Province

from time to time shall apply to the Indians within the

boundaries thereof, provided, however, that the said Indians shall have the right, which the

Province hereby assures to them, of hunting, trapping and fishing game and fish for food at all seasons of the year on all unoccupied Crown lands and on any other lands to which the said Indians may have a right of access. 